
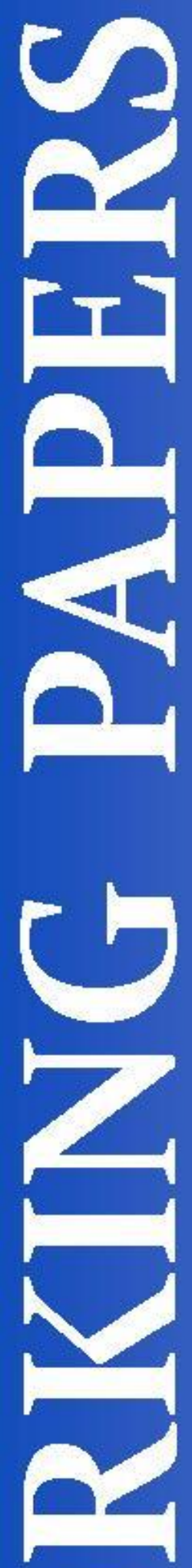

Evaluating local government performance in times of crisis

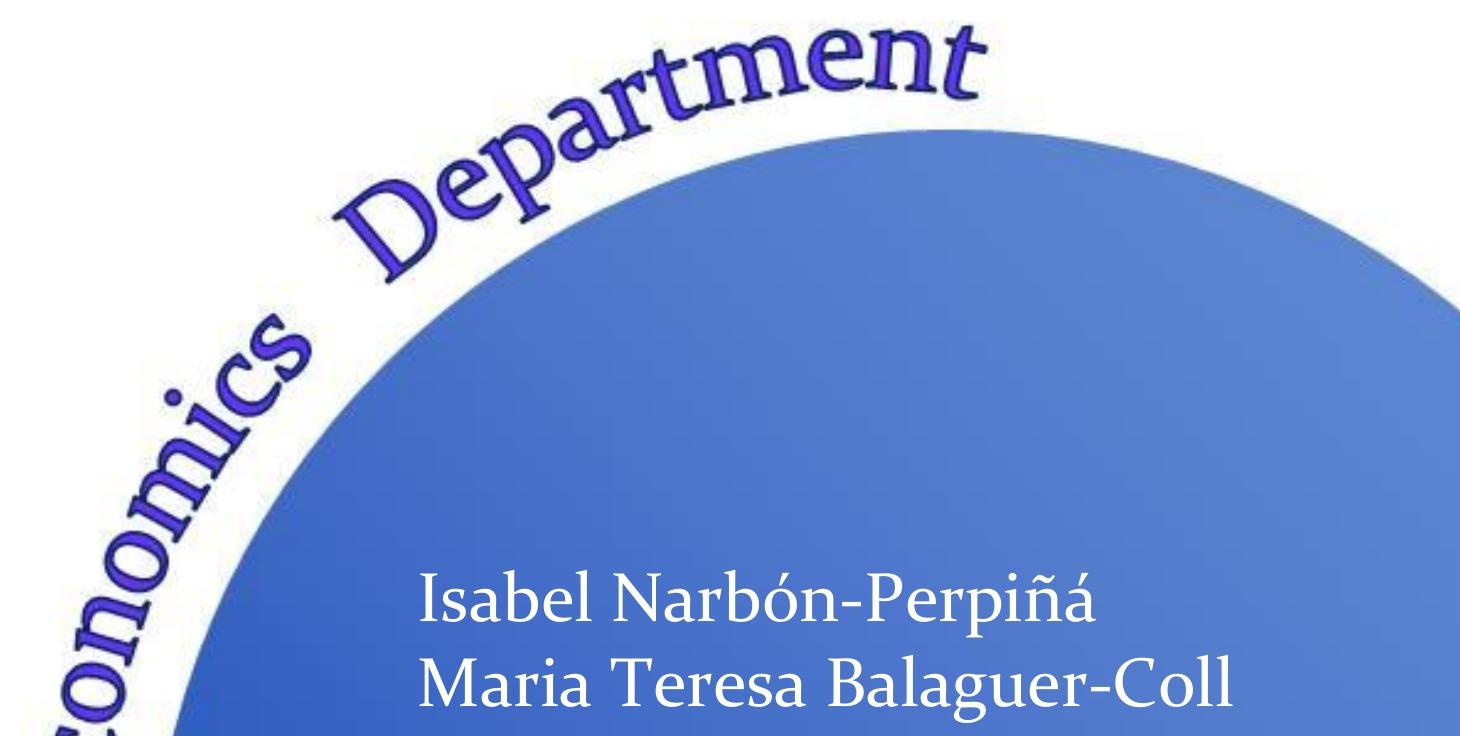

II

Emili Tortosa-Ausina 


\title{
Evaluating local government performance in times of crisis
}

\author{
Isabel Narbón-Perpiñá \\ Universitat Jaume I \\ Department of Economics \\ narbon@uji.es
}

\author{
$M^{a}$ Teresa Balaguer-Coll \\ Universitat Jaume I \\ Dept of Accounting and Finance \\ bcoll@uji.es
}

\author{
Emili Tortosa-Ausina \\ IVIE \& Universitat Jaume I \\ Department of Economics \\ tortosa@uji.es
}

\section{7 / 05}

\begin{abstract}
In the recent years of international economic crisis, Spanish local governments have come under increasing pressure to accommodate severe economic restrictions while maintaining (or even increasing) their provision of local public services. This paper aims to analyse overall cost efficiency in Spanish local governments during the period of the economic crisis (2008-2013) which has scarcely been examined to date. To this end, we measure efficiency, for which we consider four different non-parametric methodologies. Moreover, given how problematic it is to precisely define the bundle of services and facilities that municipalities must provide, we compare three different output models in which we consider measures of quantity as well as quality. Our results suggest that Spanish local government efficiency improved over the crisis period 2008-2013 since budget expenditures (inputs or costs) fell while local public services and facilities (outputs) were maintained. We also find evidence of the possible implications of service quality when measuring local governments' cost efficiency, and of structural differences in the average efficiency between municipalities located in different Spanish regions and provinces. Finally, our results confirm that the level and variation of efficiency scores are affected by the approach taken.
\end{abstract}

Keywords: Efficiency, local government, non-parametric frontiers

JEL classification: C14, H11, H70, R15 


\title{
Evaluating local government performance in times of crisis
}

\author{
Isabel Narbón-Perpiñá \\ Universitat Jaume I
}

\author{
Maria Teresa Balaguer-Coll \\ Universitat Jaume I
}

\author{
Emili Tortosa-Ausina \\ Universitat Jaume I and Ivie
}

April 5, 2017

\begin{abstract}
In the recent years of international economic crisis, Spanish local governments have come under increasing pressure to accommodate severe economic restrictions while maintaining (or even increasing) their provision of local public services. This paper aims to analyse overall cost efficiency in Spanish local governments during the period of the economic crisis (2008-2013) which has scarcely been examined to date. To this end, we measure efficiency, for which we consider four different non-parametric methodologies. Moreover, given how problematic it is to precisely define the bundle of services and facilities that municipalities must provide, we compare three different output models in which we consider measures of quantity as well as quality. Our results suggest that Spanish local government efficiency improved over the crisis period 2008-2013 since budget expenditures (inputs or costs) fell while local public services and facilities (outputs) were maintained. We also find evidence of the possible implications of service quality when measuring local governments' cost efficiency, and of structural differences in the average efficiency between municipalities located in different Spanish regions and provinces. Finally, our results confirm that the level and variation of efficiency scores are affected by the approach taken.
\end{abstract}

Keywords: efficiency, local government, non-parametric frontiers

JEL Classification: C14, H11, H70, R15

\footnotetext{
*We thank Paula Bel, Víctor Giménez, Diego Prior and José Luis Zafra for helpful comments. All authors acknowledge the financial support of the Ministerio de Economía y Competitividad (ECO2014-55221-P), Generalitat Valenciana (PROMETEOII/2014/046) and Universitat Jaume I (P1.1B2014-17 and PREDOC/2013/35). The usual disclaimer applies.
} 


\section{Introduction}

Over the last few years, improving public management efficiency has been a growing concern in many developed and developing countries, partly due to the new public finance scenarios resulting from the international economic crisis. However, other mechanisms have also operated in certain contexts. This is the case in the European Union, where the Stability and Growth Pact (SGP) stipulates that all governments should prioritise managing their resources efficiently in order to contribute to the viability of the European Economic and Monetary Union. Since 2011, the SGP has undergone several reforms in order to better consider each country's specific circumstances, and to strengthen the rules concerning budget deficits or public debt burdens. ${ }^{1}$ Therefore, in a context in which the financial crisis has challenged public finances in several euro area and non-euro area countries, leading to unprecedented increases in some countries, efficient management of resources at all levels of government (central, regional and municipal) has become essential (Balaguer-Coll et al., 2013).

We focus on Spain, a country that has not escaped the effects of this international scenario (Barreiro and Sánchez-Cuenca, 2012). The crisis that started in 2007, together with the bursting of the housing bubble ${ }^{2}$ in 2008 , led the country into a deep recession and became a priority issue $^{3}{ }^{4}$ for the Eurozone in 2012. Thus, in response to the macroeconomic situation, the Spanish government adopted austerity programmes that advocated higher taxes and reduced public spending in order to meet budgetary stability targets. In a decentralised country such as Spain, the central government's budgeting efforts would be of little use if they were not backed by lower levels of government (Cabasés et al., 2007). The framework for budgetary

\footnotetext{
${ }^{1}$ In 2013, the SGP was reformed through a collection of new laws, known as the "Six Pack". It laid down detailed rules for national budgets to ensure EU governments respect the requirements of economic and monetary union and do not run excessive deficits. In 2014 the SGP was further strengthened by new laws, known as the "Two Pack", as well as budgetary targets set by a law known as the "Fiscal Compact". Taken from the History of the Stability and Growth Pact (SGP), https://ec.europa.eu/info/business-economy-euro/economicand-fiscal-policy-coordination/eu-economic-governance-monitoring-prevention-correction/stability-and-growthpact/history-stability-and-growth-pact. Last accessed 23.3.17

${ }^{2}$ In 2007 the construction sector represented 13\% of Spain's gross domestic product (GDP). Low interest rates and the expansion of the Spanish savings banks (Cajas de Ahorros) substantially contributed to a construction boom that turned into a "bubble", which burst when borrowing was severely curtailed after the fall of Lehman Brothers in 2008 (Almendral, 2013).

${ }^{3}$ Traynor, I. and Watt, N. (6 June 2012). "Spain calls for new tax pact to save euro: Madrid calls for Europe-wide plan but resists 'humiliation' of national bailout". The Guardian. Retrieved from https://www.theguardian.com/business/2012/jun/06/spain-euro-finished-fiscal-union, last accessed 23.3.17

${ }^{4}$ Forell, C. and Steinhauser, G. (11 June 2012). "Latest Europe Rescue Aims to Prop Up Spain". Wall Street Journal. Retrieved from http://www.wsj.com/articles/SB10001424052702303768104577458562351966868, last accessed 23.3.17
} 
stability in Spain was therefore enacted in the General Budget Law, ${ }^{5}$ which introduced more control over public debt and public spending at all levels of government with the aim of achieving a balanced budget.

Turning to the context of this study, local governments are responsible for a significant number of public powers (Devas and Delay, 2006; Da Cruz and Marques, 2014), although this varies among countries. For instance, since the approval of the 1978 Constitution, in Spain local governments have played an important role in providing public services, and form a sub-sector whose powers have increased over time-although modestly compared with higher (regional) levels of government (Vilalta Ferrer, 2010). However, municipalities have seen their resources severely reduced since the severe impact of the economic crisis on most of their revenues (Pérez López et al., 2013), as well as stricter budget limitations. The decline in municipal revenues combined with harsh budget constraints has therefore made the task of managing available resources with maximum efficiency an even greater challenge. Under these circumstances, issues related to Spanish local government efficiency and their contribution to public sector deficit are more relevant than ever.

The economic crisis has highlighted improving efficiency and reducing the costs of local public services as prime areas of concern (Andrews and Boyne, 2011; Pérez-López et al., 2015). However, Spanish local governments have come under increasing pressure to improve efficiency, while maintaining (or even increasing) the provision of local public services. As local government is the closest level of government to its citizens, it has a first-hand impression of society's demands (Martín et al., 2011). Therefore, performance measurement may successfully support local public organisations in their effort to increase the value for money in service provision (Lo Storto, 2016) in order to provide the best possible local services at the lowest possible cost. Taking this premise as our starting point, one of the aims of this study is to analyse overall cost efficiency in Spanish municipalities during the economic crisis period (2008-2013), a subject yet to be examined in depth. Specifically, we attempt to learn whether Spanish local governments have succeeded in reducing their budget expenditures while maintaining public service provision; in other words, whether local government cost efficiency has improved in times of crisis.

Regardless of the context of analysis, one of the most significant tasks in efficiency mea-

\footnotetext{
${ }^{5}$ Ley General Presupuestaria $(2007,2012)$, or or General Budget Law.
} 
surement is the proper definition of inputs and outputs (Štastná and Gregor, 2015). Unfortunately, a common problem in local government efficiency analysis ${ }^{6}$ is the complexity of accurately defining and measuring local governments' inputs and outputs (Balaguer-Coll et al., 2013). This complexity is due to the difficulty of collecting data and measuring local services. Indeed, studies use diverse input and output measures, even when analysing efficiency with data from the same country. In the Spanish case, some studies consider only the minimum services all local governments are obliged to provide (Giménez and Prior, 2007), others analyse the minimum services and a quality variable (Balaguer-Coll et al., 2007; Zafra-Gómez and Muñiz-Pérez, 2010), and a third group examine the complete range of services provided by local governments (Balaguer-Coll et al., 2010, 2013).

Given how problematic it is to define the bundle of services and facilities that municipalities must provide, we consider it reasonable to propose three separate output models in order to assess whether different choices might explain variations among local governments, and to determine how the number of outputs can affect efficiency scores. We use a comprehensive database, which includes measures of both quantity and quality of the services and facilities provided. The inclusion of quality variables in the analysis is interesting and informative for local governments, since performance decisions may have an impact on their quality, but not on their quantity. In addition, the study contributes through the sample selected for analysis. While other studies using Spanish data focus on a specific region or year, our study examines a much larger sample of various regions over several years, specifically,1,574 Spanish local governments with populations between 1,000 and 50,000 for the period 2008-2013. This sample allows investigation of structural differences in the average efficiency scores between municipalities located in different Spanish regions and provinces for the first time in the literature.

Moreover, the vast majority of previous studies have applied just one frontier technique, in most cases DEA (Data Envelopment Analysis), FDH (Free Disposal Hull) or SFA (Stochastic Frontier Approach). Only a few authors (De Borger and Kerstens, 1996a; Geys and Moesen, $2009 b$ ) apply two or more alternative approaches to analyse public efficiency. Since there is no obvious way to choose an efficiency estimator, the method selected may affect the efficiency analysis (Geys and Moesen, 2009b) and could provide "unfair" or biased results. In this con-

\footnotetext{
${ }^{6}$ For a comprehensive literature review on efficiency measurement in local governments see Narbón-Perpiñá and De Witte (2017a) and Narbón-Perpiñá and De Witte (2017b).
} 
text in which there is no commonly accepted methodology to measure efficiency, we must be cautious when interpreting results from research studies using one particular method, since their results might be affected by which approach was selected. It is therefore important to assess the robustness of the estimated efficiency by comparing different methodologies (Da Silva et al., 2016). In light of the efficiency estimator selection problem, the present investigation also contributes to the literature by providing a comparative perspective using not only different specifications for inputs and outputs, but also several non-parametric methodologies to measure efficiency, namely, DEA, FDH, order- $m$ frontier and the bias corrected DEA estimator proposed by Kneip et al. (2008).

Our results suggest that Spanish local governments became more efficient over the crisis period 2008-2013 since their budget expenditures (inputs or costs) fell while at the same time they managed to maintain (or even increase) local public services and facilities (outputs). We find statistical evidence that service quality has possible implications when measuring local government cost efficiency. We also detect structural differences in average cost efficiency among municipalities located in different Spanish regions and provinces. Additionally, in line with previous research, our results confirm that the level and variation of efficiency scores are affected by the approach taken. We found large differences in the mean efficiency scores, ranging from 0.44 to 0.96 (also contingent on the model and the year) depending on the reference technology used. Caution is therefore essential when interpreting empirical studies that use just one method and policy-makers must carefully consider their results when taking performance decisions (Badunenko et al., 2012).

The paper is organised as follows: section 2 establishes the institutional framework of Spanish local governments. Section 3 gives an overview of the methodologies used to determine cost efficiency. Section 4 describes the data in detail. Section 5 presents and comments on the most relevant efficiency results. Finally, section 6 summarises the main conclusions.

\section{Local governments in Spain: institutional framework}

The institutional context of the Spanish public sector was formally established in the 1978 Constitution. Accordingly, Spain has three levels of government: central, regional and local, and as such, is one of the most decentralised countries in Europe (Balaguer-Coll et al., 2010). Spain has 17 autonomous communities or regions (NUTS2), 50 provinces (NUTS3) and 8,114 
municipalities (NUTS5). ${ }^{7}$

Spanish local governments are characterised by their very diverse populations and territorial distributions. In 2011, almost $83.74 \%$ of municipalities had populations below 5,000, and accounted for only $13 \%$ of the total population. Despite this diversity, because local governments are responsible for providing the most basic services, they are closer to citizens than other levels of government. Since the approval of the 1978 Constitution, local governments have played an important role in providing public services and their responsibilities have increased over time. However, their share of total public spending has remained relatively stable during this period, at least when compared to regional governments. ${ }^{8}$ Table 1 shows the distribution of total public expenditures among central, regional and local levels. As can be seen, while regional governments' share of total public spending has increased at the expense of central government, local government spending remains stable at around 15\%.

The Constitution also recognises local municipal autonomy to manage their responsibilities. This principle guarantees their right to participate in the affairs that affect their interests, meaning that municipalities can manage and assume responsibility for a substantial share of public undertakings for the benefit of their inhabitants. Local autonomy is therefore reflected in their financial resources as well as their competencies.

With regard to their financial structure, local government revenues come mainly from local taxes, the most relevant being property taxes (IBI, Impuesto de Bienes Inmuebles), transfers received from central government, and fees paid for the use of public infrastructures or provision of public services. Table 2 shows the most important revenue categories in municipal budgets for the years 2008-2013. Note that although municipalities are considered financially autonomous by law, they only generated $54.07 \%$ of their total revenues in 2008-2013 from their own resources (i.e., through taxes, fees, property incomes and sale of fixed assets ) while transfers from other levels of government accounted for $27.08 \%$ and financial transactions, $19.98 \%$.

As regards local government competencies, the distribution of basic municipal powers is established in the 1985 Spanish local government law (Ley 7/1985 Reguladora de Bases de Régimen Local). Article 26 of this law establishes the minimum services and facilities that each

\footnotetext{
${ }^{7}$ Data from INE (Instituto Nacional de Estadística, Spanish Statistical Office), January 2011.

${ }^{8}$ Regional governments have been gaining powers at the expense of central government at a greater rate than local governments (see, Balaguer-Coll et al., 2007, 2010).
} 
municipality must provide, according to their size. In addition, articles 25, 27 and 28 of the law consider that local powers also depend on central or regional government legislation, and state that municipalities can take the initiative to exercise complementary activities for other specific purposes. This open framework may therefore lead to disparities in the services municipalities provide. The law only establishes the minimum services; however, it does not prevent municipalities from going beyond this legal minimum and offering not only more quantity or improved quality of a particular compulsory service, but also additional services and facilities (Balaguer-Coll et al., 2013). Table 3 reports the services and facilities Spanish local governments provide as stipulated by law.

\section{Methodologies}

In the present study, we focus on the efficiency of public goods and service provision. Efficiency analysis can be defined as a comparison among a group of decision-making units or DMUs (in our case, Spanish local governments), in order to evaluate how the available resources (or inputs) are used to produce local services and facilities (or outputs). ${ }^{9}$ Different types of efficiency can be distinguished, depending on the available data for inputs and outputs. Hence, technical efficiency requires data on input and output quantities, while allocative efficiency requires additional information on input prices. Moreover, these two measures can be combined to obtain economic efficiency, also called cost efficiency ${ }^{10}$ — when the economic objective is cost minimisation (although revenue efficiency and profit efficiency may also be considered). However, if data on costs are available but data on prices and physical units are not, cost efficiency can be measured but not decomposed (Balaguer-Coll et al., 2007). It should be noted that public sector goods and services are frequently unpriced due to their non-market nature (Kalb et al., 2012). In this context, since there are no data available on input prices, in the present study we measure local government cost efficiency using data in municipal budgets as input costs.

In addition, we consider four different non-parametric techniques to measure cost efficiency, namely, Data Envelopment Analysis (DEA) (Charnes et al., 1978; Banker et al., 1984), Free Disposal Hull (FDH) (Deprins et al., 1984), order-m (Cazals et al., 2002), and Kneip et al.'s

\footnotetext{
${ }^{9}$ See Coelli et al. (2005) and Fried et al. (2008) for an introduction to efficiency measurement.

${ }^{10}$ Cost Efficiency $(C E)=$ Technical Efficiency $(T E) \cdot$ Allocative Efficiency $(A E)$
} 
2008 bias corrected DEA estimator, henceforth KSW. The former two techniques are the most popular in the non-parametric field, whereas the latter two are relatively recent proposals. We focus on non-parametric as opposed to parametric methodologies, due to their less restrictive assumptions and greater flexibility. ${ }^{11}$ In addition, parametric and non-parametric methodologies have not evolved in parallel, and several proposals have leaned towards the non-parametric field, overcoming most of their limitations in the process (Daraio and Simar, 2007; Bădin et al., 2014).

\subsection{Data Envelopment Analysis (DEA) and Free Disposal Hull (FDH)}

DEA (Charnes et al., 1978; Banker et al., 1984) is a non-parametric methodology based on linear programming to estimate and compare the relative efficiency of decision-making units (DMUs). DEA defines an empirical frontier which creates an "envelope" determined by the efficient DMUs. These units, located on the frontier, are considered "best-practice" units and have an efficiency score equal to 1 . In the case of input orientation (which in our case is reasonable, as we will see below), units above the frontier are considered inefficient and have a score lower than 1 . The distance between each DMU and the frontier shows the measure of its inefficiency. The most important assumptions of the model are: returns to scale, convexity and free disposability of inputs and outputs.

As indicated above, and similarly to previous studies on local government efficiency, we consider an input-oriented DEA model (Sampaio de Sousa and Stošić, 2005; Balaguer-Coll et al., 2007) because outputs are established externally in the public sector (the minimum services that local governments must provide) and, consequently, it is more appropriate to evaluate efficiency in terms of input minimisation (Balaguer-Coll and Prior, 2009). Moreover, because local governments differ considerably in size, we assume variable returns to scale (Balaguer-Coll and Prior, 2009; Bosch-Roca et al., 2012; Doumpos and Cohen, 2014; Da Cruz and Marques, 2014). This has the added advantage that each municipality is only compared to other municipalities of the same size.

We introduce the mathematical formulation for the cost efficiency measurement (Färe et al., 1994). The minimal cost efficiency can be calculated by solving the following programme for

\footnotetext{
${ }^{11}$ For a detailed review of the main differences between parametric and non-parametric frontier techniques, see Murillo-Zamorano (2004) and Bogetoft and Otto (2010).
} 
each local government and each sample year:

$$
\begin{array}{cll}
\min _{\theta, \lambda} \theta & & \\
\text { s.t. } & y_{r i} \leq \sum_{i=1}^{n} \lambda_{i} y_{r i}, & r=1, \ldots, p \\
& \theta x_{j i} \geq \sum_{i=1}^{n} \lambda_{i} x_{j i}, & j=1, \ldots, q \\
& \lambda_{i} \geq 0, & i=1, \ldots, n \\
& \sum_{i=1}^{n} \lambda_{i}=1 &
\end{array}
$$

where for $n$ observations (municipalities) there are $q$ inputs producing $p$ outputs. The $n \times p$ output matrix, $r$, and the $n \times q$ input matrix, $j$, represent the data for all $n$ local governments. The last constraint $\left(\sum_{i=1}^{n} \lambda_{i}=1\right)$ implies variable returns to scale (VRS), which assures that each DMU is compared only with others of a similar size.

A further extension of the DEA model with variable returns to scale, called Free Disposal Hull (FDH), was proposed by Deprins et al. (1984). Its main difference from DEA is that it drops the convexity assumption. The FDH linear programming problem is defined as follows:

$$
\begin{array}{cll}
\min _{\theta, \lambda} \theta & & \\
\text { s.t. } & y_{r i} \leq \sum_{i=1}^{n} \lambda_{i} y_{r i}, & r=1, \ldots, p \\
& \theta x_{j i} \geq \sum_{i=1}^{n} \lambda_{i} x_{j i}, & j=1, \ldots, q \\
& \lambda_{i} \in\{0,1\}, & i=1, \ldots, n \\
& \sum_{i=1}^{n} \lambda_{i}=1 &
\end{array}
$$

Finally, by solving linear programming problems (1) and (2) we obtain the cost efficiency coefficient; in other words we find $\theta$, which is the optimal (minimal) input quantity of producing $y_{r}$. Since there is no data available for input prices (due to the difficulty of using market prices to measure public services), all units are assumed to face the same input prices, and we use input variables of input costs (Kalb et al., 2012).

\subsection{Robust variants of DEA and FDH}

Although the traditional non-parametric techniques DEA and FDH have been widely applied in efficiency analysis, they present several drawbacks. One limitation of both DEA and FDH is that they are sensitive to outliers and extreme values. Since these techniques envelope all data, the efficient frontier is determined by the observations that are extreme points (Simar 
and Wilson, 2008) and, as a consequence, any outliers strongly influence the estimated frontier as well as the efficiency scores of all observations. This problem can be addressed by using "partial" frontiers, which are more robust to extremes or outliers in data. Moreover, these "partial" estimators do not suffer from the "curse of dimensionality", 12 a major problem that generally affects efficiency scores obtained using DEA and FDH Daraio and Simar (2007). Finally, another considerable drawback of traditional non-parametric approaches is the difficulty of making statistical inference. However, bootstrap methods such as those proposed by Simar and Wilson $(1998,2000)$ enable statistical inferences (consistency analysis, bias correction, confidence intervals, test of hypothesis and so on) about efficiency.

Hence, in this paper we consider two variants of DEA and FDH estimators that are able to overcome most of the drawbacks of the traditional non-parametric methods. We use the order- $m$ approach, which is a partial frontier that mitigates the influence of outliers, extreme values and the curse of dimensionality; and Kneip et al.'s 2008 bias corrected DEA estimator (KSW), which allows for consistent statistical inference by applying bootstrap techniques.

\subsubsection{Order- $m$}

Order- $m$ frontier (Cazals et al., 2002) is a robust alternative to DEA and FDH estimators that involves the concept of partial frontier, as opposed to the traditional full frontier. The order- $m$ estimators, for finite $m$ units, do not envelope all data points and consequently are less extreme. The benchmark in the input orientation case is the expected minimum input achievable among a fixed number of $m$ units producing at least output level $y$. Hence, the order- $m$ input efficiency score (Daraio and Simar, 2007) is given by:

$$
\hat{\theta}_{m}(x, y)=E\left[\left(\hat{\theta}_{m}(x, y) \mid Y \geqslant y\right)\right]
$$

The value $m$ represents the number of potential units against which we benchmark the analysed unit (i.e., how efficient a local government is compared with $m$ local governments.). If $m$ goes to infinity, the order- $m$ estimator converges to FDH. Daraio and Simar (2005) suggest that the most reasonable value for $m$ is determined as the value for which the number of

\footnotetext{
${ }^{12}$ As Daraio and Simar (2007) note, the "curse of dimensionality" implies that an increase in the number of inputs or outputs, or a decrease in the sample under analysis (i.e., the number of units for comparison), entails higher efficiencies.
} 
super-efficient observations becomes constant. In our setting, we consider $m=350$, although alternative values delivered similar outcomes.

Note that order- $m$ scores are not bounded at 1 . A value greater than 1 indicates superefficiency, showing that the unit operating at level $(x, y)$ is more efficient than the average of $m$ peers randomly drawn from the population of units producing more output than $y$ (Daraio and Simar, 2007).

\subsubsection{Bias corrected DEA estimator of Kneip et al. (2008) (KSW)}

The KSW (Kneip et al., 2008) is a bias corrected DEA estimator which derives the asymptotic distribution of DEA via bootstrapping techniques. Simar and Wilson (2008) note that DEA and FDH estimators are biased by construction, meaning that the true frontier would be located under the DEA estimated frontier. As a consequence, DEA scores (i.e., relative to the estimated frontier) are too optimistic. In the words of Badunenko et al., the bootstrap procedure to correct this bias, based on sub-sampling, "uses the idea that the known distribution of the difference between estimated and bootstrapped efficiency scores mimics the unknown distribution of the difference between the true and the estimated efficiency scores" (Badunenko et al., 2012). In addition, the KSW procedure allows for consistent statistical inference of efficiency estimates (i.e., bias and confidence intervals for the estimated efficiency scores).

Therefore, in order to implement the bootstrap procedure (based on sub-sampling), first let $s=n^{d}$ for some $d \in(0,1)$, where $n$ and $s$ are the sample and sub-sample size, respectively. The optimal $d$ depends on the dimensionality of the problem. The bootstrap then considers the following scheme:

1. First, a bootstrap sample $S_{s}^{*}=\left(X_{i}^{*}, Y_{i}^{*}\right)_{i=1}^{s}$ is generated by drawing (independently, uniformly and with replacement) $s$ observations from the original sample, $S_{n}$.

2. The DEA estimator is applied, where the technology set is constructed with the subsample drawn in step (1), to construct the bootstrap estimates $\hat{\theta}^{*}(x, y)$.

3. Steps (1) and (2) are repeated $B$ times, using the resulting bootstrap values to approximate the conditional distribution of $s^{2 /(p+q+1)}\left(\frac{\hat{\theta}^{*}(x, y)}{\theta^{*}(x, y)}-1\right)$, which allows us to approximate the unknown distribution of $n^{2 /(p+q+1)}\left(\frac{\hat{\theta}^{*}(x, y)}{\theta^{*}(x, y)}-1\right)$. The values $p$ and $q$ are the out- 
put and input quantities, respectively. The bias-corrected DEA efficiency score, which is adjusted by the $s$ sub-sample size, is given by:

$$
\theta_{b c}(x, y)=\theta^{*}(x, y)-\text { Bias }^{*}
$$

where the bias is adjusted by employing the $s$ sub-sample size.

$$
\text { Bias }^{*}=\left(\frac{s}{n}\right)^{2 /(p+q+1)}\left[\frac{1}{B} \sum_{b=1}^{B} \hat{\theta}_{b}^{*}(x, y)-\theta^{*}(x, y)\right]
$$

\section{Sample, variables and model specification}

We carry out the analysis for a sample of Spanish local governments in municipalities with between 1,000 and 50,000 inhabitants for the 2008-2013 period. The information on inputs and outputs comes from the Spanish Ministry of the Treasury and Public Administrations (Ministerio de Hacienda y Administraciones Públicas). Outputs were obtained from a survey on local infrastructures and facilities (Encuesta de Infraestructuras y Equipamientos Locales). This survey has only been published annually since 2008 (previously it was five-yearly), so in contrast to previous studies for Spain we have yearly data available for our full sample period. The study is therefore also relevant in terms of the sample analysed. While other studies based on Spanish data focus on a specific region or year, our study examines a sample of Spanish municipalities comprising various regions over several years. Information on inputs was obtained from local governments' budget expenditures.

The final sample contains 1,574 municipalities for every year (representing 19.60\%), after eliminating all the municipalities with unavailable data on inputs and outputs for the period 2008 to 2013. Specifically, there was no information for the Basque Country, Navarre ${ }^{13}$, Catalonia and Madrid regions and the provinces of Burgos, Huesca, Guadalajara and Huelva. In Table 4 we summarise the number of observations for each region in our sample.

\footnotetext{
${ }^{13}$ The Basque Country and Navarre are not obliged to present this information to the Spanish Ministry of the Treasury and Public Administrations because they have their own autonomous systems and are therefore not included in the State Economic Cooperation.
} 


\subsection{Modelling the costs of municipalities}

The costs (inputs) are derived from the local governments' budget expenditures and are representative of the cost of the municipal services provided. Using budget expenditures as inputs is consistent with the literature (e.g., Balaguer-Coll et al., 2007, 2010; Zafra-Gómez and MuñizPérez, 2010; Kalb et al., 2012; Štastná and Gregor, 2015; Fogarty and Mugera, 2013; Doumpos and Cohen, 2014; Da Cruz and Marques, 2014). Local budget expenditures are divided into two main groups: non-financial transactions and financial transactions. In turn, non-financial transactions comprise two categories: current or ordinary expenditures, and capital expenditures. The first of these categories is divided into personnel expenses, current expenditures on goods and services, financial expenditures (interests and banking expenses) and current transfers (grants and assistance to other entities). The second category, capital expenditures, is divided into real investments and capital transfers (grants or payments to entities for real investments). The second group, financial transactions, is divided into financial assets and financial liability (referring to loans and deposits, and their repayments).

The input measure therefore includes various municipal expenditures. It represents the total local government costs $\left(X_{1}\right)$, by including personnel expenses, expenditures on goods and services, current transfers, capital investments and capital transfers.

\subsection{Defining the outputs of municipalities}

Outputs are related to the specific services and facilities provided by each municipality. Most previous studies in European countries include output variables such as road infrastructure, recreational facilities, waste collection, drinking water supply, social services, primary and secondary education and health care (e.g., Afonso and Fernandes, 2008; Geys and Moesen, 2009a; Kalb et al., 2012; Štastná and Gregor, 2015). Differences in the Spanish case concern the area of education, care for elderly, and health services, which are not local government responsibilities.

Our modelling of outputs is based on the minimum services and facilities that each municipality is legally obliged to provide, according to their size. These compulsory services are listed in Article 26 of the Spanish local government law (Ley reguladora de Bases de Régimen Lo$\mathrm{cal}^{14}$ ) Specifically, all local governments must provide public street lighting, cemeteries, waste

\footnotetext{
${ }^{14}$ Articles 25 to 28 of this law were amended in 2013Ley 27/2013, de 27 de diciembre, de racionalización y sosteni-
} 
collection and street cleaning services, drinking water to households, sewage system, access to population centres, paving of public roads, and regulation of food and drink. Furthermore, larger municipalities with populations of over 5,000, 20,000 or 50,000 (the limits that define the groups) must provide additional services in accordance with the size of the specific population. The selection of outputs is consistent with previous studies on efficiency in Spanish local governments (e.g., Balaguer-Coll et al., 2007; Balaguer-Coll and Prior, 2009; Zafra-Gómez and Muñiz-Pérez, 2010; Bosch-Roca et al., 2012) as well as in other European countries, since for the most part they have similar competencies (e.g., Da Cruz and Marques, 2014; Doumpos and Cohen, 2014). However, article 26 of this law was modified in 1996, removing the obligation to provide an abattoir; we therefore do not include it in this study, in contrast to previous studies in Spain. In addition, we have added four new variables, including measures for sewage system provision (a compulsory service for all local governments which has not previously been taken into account).

In order to generate a balanced set of outputs that reflects all the services and facilities municipalities are legally obliged to provide, we have a final list of 10 output variables. ${ }^{15}$ Due to the difficulty of measuring public sector outputs, in some cases proxy variables must be used, a strategy that has been widely applied in the literature. Based on the study of De Borger and Kerstens (1996a,b), many of these output variables should be considered as crude proxies for municipal services because more direct outputs are not available.

Population size $\left(Y_{1}\right)$, is used as a proxy for the following services: cemetery, regulation of food and drink, civil protection and social service provision. Street infrastructure surface area $\left(Y_{2}\right)$ is used as a proxy for street cleaning, access to population centres, paving of public roads, and fire prevention and extinction. Some services have direct output measures such as public street lightning (calculated by the number of lighting points, $Y_{3}$ ), waste collection and treatment of waste collected (calculated by the tons of waste collected, $Y_{4}$ ), supply of drinking water to households (measured by the length of the water distribution network, $Y_{5}$ ), the sewage system (measured by the length of the sewage networks, $Y_{6}$ ), public parks

bilidad de la Administración Local to clarify municipal powers, rationalise local government organisational structure in accordance with the principles of efficiency, stability and financial sustainability, and ensure more rigorous financial and budgetary control.

${ }^{15}$ Although the number of output variables is relatively high compared with previous literature, we have, in general, a more complete and much larger database. We have data available containing the services that municipalities must provide and measures of their quality, including several Spanish regions for several years. 
(measured by the surface area of public parks, $Y_{7}$ ), public library (measured by the surface area of public libraries, $Y_{8}$ ), market (measured by the market surface area, $Y_{9}$ ) and public sports facilities (measured by the sport facilities surface area, $Y_{1} 0$ ).

Finally, following Balaguer-Coll et al. (2007), Balaguer-Coll and Prior (2009) and ZafraGómez and Muñiz-Pérez (2010), we also incorporate service quality into the analysis. These data are not usually included in the literature, although they are of interest to and informative for local governments, since performance decisions may have an impact on their quality and not on their quantity. Because services and facilities for each municipality are classified as "good", "fair" or "bad" according to their condition, we include these categories in the output variables explained above, weighting by the quantity of service provided:

$$
Y_{p i}^{q u a l i t y}=\frac{Y_{p i} Q_{z i}}{\sum_{i=1}^{n} Y_{p i}}
$$

where for each $i=1, \ldots, n$ local government, $Y_{p i}$ is the quantity of output $p$, and $Q_{z i}$ is the quality category, $z=1,2,3$.

Table 5 reports the minimum services that each local government must provide according to their size for the period 2008-2013 and the different output indicators used to evaluate the services.

\subsection{Model specifications}

Unlike previous Spanish studies that only consider the minimum services all local governments are obliged to provide (Giménez and Prior, 2007), the minimum services and a quality variable (Balaguer-Coll et al., 2007; Zafra-Gómez and Muñiz-Pérez, 2010), or the total range of services provided by local governments (Balaguer-Coll et al., 2010, 2013), we compare how different output specifications affect efficiency scores.

Moreover, in relation to the number of outputs included in the efficiency analysis, we must take into account the problem of dimensionality. A general guideline to establish the number of variables is that the number of observations (i.e., local governments) should be at least twice the number of inputs and outputs considered (Golany and Roll, 1989); hence, following this rule, as the number of units increases, more variables can be incorporated in the analysis. However, including a large number of variables can result in a large number of efficient units. 
We considered it reasonable to specify three output models in order to assess whether different choices might explain the variations between local governments, and to determine how the number of outputs can affect the efficiency scores. The more encompassing the models are (i.e., more outputs are included in the model), the higher the efficiency (since municipalities have more dimensions in which to excel). Therefore, considering different models will provide us with a more precise view of municipalities' efficiency. The three output models are as follows:

Model 1 includes measures of compulsory minimum services for all governments: number of lighting points, total population, tons of waste collected, street infrastructure surface area $\left(m^{2}\right)$, length of water distribution networks $(m)$, and length of sewage networks $(m)$.

Model 2 includes measures of compulsory minimum services for all governments along with additional services that larger municipalities with populations of over 5,000 or 20,000 must provide: number of lighting points, total population, tons of waste collected, street infrastructure surface area $\left(\mathrm{m}^{2}\right)$, length of water distribution networks $(m)$, length of sewage networks $(m)$, public parks surface area $\left(m^{2}\right)$, public library surface area $\left(m^{2}\right)$, market surface area $\left(m^{2}\right)$ and sports facilities surface area $\left(m^{2}\right)$.

Model 3 introduces all the services provided by local governments taking into account the quality of the services weighted by their quantity. ${ }^{16}$

Table 6 shows the descriptive statistics for inputs and outputs for the period 2008-2013. We include the median rather than the mean to avoid distortion from outliers.

\section{Efficiency results}

We estimate efficiency scores for 1,574 municipalities for the 2008-2013 period using the methodologies explained in the previous sections. Tables 7, 8 and 9 report overall costefficiency results averaged over all municipalities for each year in Models 1, 2 and 3, re-

\footnotetext{
${ }^{16}$ Different definitions can be applied to include service quality. Indeed, the studies of Balaguer-Coll et al. (2007), Balaguer-Coll and Prior (2009) and Zafra-Gómez and Muñiz-Pérez (2010) included service quality as a single output variable. However, since we aim to compare the efficiency scores with and without including service quality in the analysis, we consider it appropriate to weight the quality of each service by its quantity in order to maintain the same number of variables as output Model 2.
} 
spectively. They show summary statistics, including the mean and the standard deviation, as well as additional statistics which provide deeper insights into the distributions of efficiency scores. The last column in each table reports the percentage of efficient local governments.

We also provide violin plots to aid further interpretation of results. They include all features of the distribution and offer more thorough information on how each methodology behaves. Figures 1 and 2 display the violin plots for DEA and FDH, and order- $m$ and KSW approaches, respectively. ${ }^{17}$ We report results for the three models considered, in order to assess whether different output specifications might contribute to explain variations between local governments, and to determine how the number of outputs can affect efficiency scores.

\subsection{Evaluating cost efficiency with different non-parametric methodologies}

Caution is needed when interpreting results from studies using just one method since the approach taken might lead to different efficiency levels. Therefore, as De Borger and Kerstens (1996a) note, a good strategy is to use different methodologies to check for robust efficiency scores. We now discuss some descriptive statistics for each of the four cost-efficiency measures.

When comparing DEA and FDH, both efficiency scores and the percentage of cost-efficient local governments are higher under FDH than under DEA. Note that FDH drops the convexity assumption underlying DEA and, as a result, it yields a higher number of efficient units. Therefore, all DEA efficient observations are also efficient under FDH (De Borger and Kerstens, 1996a). In addition, the increase in the number of outputs from Model 1 to Models 2 and 3 implies higher efficiency scores for both methodologies, since DEA and FDH estimators notoriously suffer from the "curse of dimensionality" (see Daraio and Simar (2007), for further discussion).

A comparison of DEA and KSW methodologies shows that the average cost efficiency scores using KSW are lower than those obtained with the DEA approach. Moreover, under KSW most local governments are found to be inefficient (i.e., we observe $0 \%$ of efficient local governments in most of the years analysed). By construction, KSW methodology takes the standard DEA estimator to correct its bias and, as a consequence, municipalities considered

\footnotetext{
${ }^{17}$ For visual simplicity, we plot together years from 2009 to 2012; however they do not differ greatly and individual plots are available upon request.
} 
as efficient when using DEA (i.e., municipalities located in the frontier with an efficiency score of 1), are considered inefficient in KSW because their bias has been corrected (i.e., municipalities could be close to an efficiency score of 1 , but they are no longer considered efficient). KSW methodology is therefore useful for ranking the observations (i.e., relative ordering of municipalities) but not for identifying the benchmark units.

The order- $m$ approach yields higher efficiency scores and percentages of efficient units than all the other methods. Order- $m$ is more robust to extreme values and outliers, giving more prudent results than FDH. Note that order- $m$ scores are not bounded by 1 , and a value greater than 1 indicates super-efficient units.

Violin plots from figures 1 and 2 support the descriptive analysis from above. DEA figures present uni-modal structures for Model 1 and 2, indicating tighter probability masses of inefficient units around 0.55. In addition, Model 3 shows a bi-modal structure with an additional mode at unity, which are the cost efficient units. In FDH, the tighter probability masses are concentrated at unity, which show the large amount of cost-efficient units. We observe that figures from both methods give evidence that an increase in the number of outputs (from Model 1 to 2 and 3) implies a higher probability mass around unit (i.e., an increase of efficient units). Moreover, despite the mode is higher in DEA than in KSW plots, there do not seem to be large differences in the cost structures between both methods. Finally, order- $m$ figures show a higher dispersion of the efficiency scores (there are super-efficient units with efficiency scores greater than 1), with a tighter probability mass around 0.90 .

Violin plots from Figures 1 and 2 support the above descriptive analysis. DEA figures present uni-modal structures for Models 1 and 2, indicating tighter probability masses of inefficient units around 0.55. In addition, Model 3 shows a bi-modal structure with an additional mode at unity, which are the cost efficient units. In FDH, the tighter probability masses are concentrated at unity, showing the large number of cost-efficient units. Figures from both methods provide evidence that an increase in the number of outputs (from Model 1 to 2 and 3) implies a higher probability mass around unity (i.e., an increase of efficient units). Moreover, although the mode is higher in DEA than in KSW plots, there do not seem to be large differences in the cost structures between the two methods. Finally, order- $m$ figures show a higher dispersion of the efficiency scores (there are super-efficient units with efficiency scores greater than 1) with a tighter probability mass around 0.90 . 


\subsection{Evaluating cost efficiency with different output models}

General discrepancies are observed on comparing the results yielded by the different models (output specifications). As expected, the selection of outputs affects the efficiency results. There are some differences between Model 1 and Models 2 and 3, which can be partly explained by the different number of outputs included. However, when the quality of the services is also included (Model 3), the increase in the efficiency scores might be related to the fact that more cost-efficient municipalities provide better quality services. As Balaguer-Coll et al. (2007) suggest, often local governments cannot directly affect, at least in the short term, the quantity of services and facilities; however, performance decisions may have a decisive impact on their quality.

These tendencies can be more formally tested to uncover whether or not efficiency results differ significantly when service quality is included. The methodology used to determine any significant differences between two different distributions,following Pastor and TortosaAusina (2008), Balaguer-Coll et al. (2010) and Zafra-Gómez and Muñiz-Pérez (2010), is based on the $\mathrm{Li}(1996)$ test with the variation proposed by Simar and Zelenyuk (2006). ${ }^{18}$ Since the test compares the closeness between two unknown density functions, we compare the efficiency scores from Models 2 and 3. We therefore consider the null hypothesis $H_{0}: f($ Model2 $)=$ $g$ (Model3), which means that the distribution of efficiency scores is the same with (Model 3) and without (Model 2) the inclusion of service quality, against the alternative hypothesis $H_{1}: f($ Model 2$) \neq g($ Model3 $)$. Results are provided in Table 10.

The test reveals significant differences in the efficiency scores when service quality is included, suggesting that for the municipalities in our sample there is a trade-off between cost efficiency and service quality. As a consequence, municipalities which are efficient in terms of output quantity can be inefficient in terms of output quality. These results reflect the importance of including quality variables in the analysis, since different regulatory policies or managerial decisions could have an impact on the quality of the services and not on their quantity. Violin plots in Figures 1 and 2 confirm the results. Note that there seem to be differences in the cost structures when quality is included (Model 3) and when it is not (Model 2), supporting the statistical evidence of the possible implications of service quality when

\footnotetext{
${ }^{18}$ Simar and Zelenyuk (2006) adapted the Li (1996) test when applied to efficiency scores yielded by DEA and FDH via bootstrapping techniques.
} 
measuring local government cost efficiency.

\subsection{Evaluating cost efficiency over the period 2008-2013}

Tables 7, 8 and 9 also show the evolution in the distribution of efficiency scores over the period 2008-2013. Although we do not set out to analyse the dynamics of efficiency, some tendencies can be seen. The average cost efficiency scores are not constant over the period; specifically, there is a general increase in the efficiency scores over time with all approaches.

In the context of economic crisis, Spanish local governments have been immersed in a process of budgetary reforms. The law on budgetary stability (Ley General de Estabilidad Presupuestaria) aims to streamline local expenditures in order to achieve a balanced budget. It establishes annual budgetary stability targets, and expenditure and debt rules. In these circumstances, local governments have been under pressure to accommodate severe economic restrictions while at the same time attending to citizens' needs. Our aim was therefore to analyse whether Spanish local governments have attempted to reduce their budget expenditures while maintaining the provision, and quality, of public services; that is, whether local governments' cost efficiency has improved over time.

In order to analyse the evolution of the efficiency scores for the whole period from 2008 to 2013, we test whether significant differences in efficiency levels took place between the initial and the final period, again using the Li (1996) test with the modification proposed by Simar and Zelenyuk (2006). Therefore, we consider the null hypothesis $H_{0}: f(2008)=g(2013)$, which means that the distribution of the efficiency scores in the initial year of the crisis period (2008) is equal to the distribution of the efficiency scores in the final year of the period (2013), against the alternative hypotheses $H_{1}: f(2008) \neq g(2013)$. Results are provided in 11 . The results reveal significant differences in most of the distributions of efficiency during the period 2008-2013, both in quantity and quality output models. This finding confirms that Spanish local governments have improved their efficiency levels in crisis times since they reduced their costs between 2008 and 2013, while maintaining (or even increasing) the level of services and facilities (outputs). 


\subsection{Evaluating cost efficiency by regions and provinces}

A thorough investigation also needs to understand whether there are structural differences in the average cost efficiency between municipalities located in different Spanish regions and provinces. The economic and financial crisis has seriously affected all Spanish public administrations (Balaguer-Coll et al., 2016). However, its impact has not been uniform across territories, since some of them (both regional and local levels of government) have faced higher debt increases along with larger falls in revenues, especially areas hardest hit by the effects of the housing bubble (Portillo Navarro, 2009). Indeed, the most affected areas were located in the eastern part of the Spanish peninsula and, to a greater extent, along the Mediterranean coast. In contrast, the impact was relatively moderate in the Atlantic areas, due to their diversified economies, and in some interior regions such as Castile and Leon, which had not been as heavily involved in the growth of the real estate bubble (Méndez Gutiérrez del Valle, 2015).

In addition, territorial differences in the regional financing system could also affect the provision of local public services. Note that local governments receive transfers from regional governments; hence, if the latter are underfinanced, local governments' resources may be affected. On this point, a 2014 report from the Spanish Ministry of the Treasury and Public Administrations concluded that some regions, such as the Balearic Islands, Valencian Community or Murcia, had the lowest rates per capita of funding received by the homogeneous regional powers in 2011, while the regions of Navarre, the Basque Country, La Rioja and Cantabria were the best funded. ${ }^{19}$

Therefore, given that the effects derived from the economic crisis and the regional financing system have not been equal in all Spanish territories, the local governments' location in a given territory could determine the more efficient provision of local public services. Some local entities faced an even more complicated situation, in which they had to continue providing public services with considerably lower resources but attending to their budgetary balance. In this context, we examine the existence of interregional differences showing higher or lower efficiency levels across municipalities located in different areas. Table 12 reports the descriptive statistics of the average efficiency scores classified for the Spanish regions and provinces. ${ }^{20}$

\footnotetext{
${ }^{19}$ Report from the Spanish Ministry of the Treasury and Public Administrations (Ministerio de Hacienda y Administraciones Públicas), July 2014. “Informe sobre la dimensión territorial de la actuación de las Administraciones Públicas, Ejercicio 2011". Retrieved from http:/ / www.minhafp.gob.es

${ }^{20}$ For the sake of simplicity, we focus the analysis on output Model 3 (note that we found statistical evidence of
} 
When considering the efficiency scores by regions we found that over the whole period municipalities in the region of Galicia seem to have the highest levels of efficiency. Indeed, Table 12 shows that better-performing municipalities are concentrated in the north of the country (i.e., Galicia, Cantabria and Asturias). Moreover, a comparison of provinces' efficiency scores reveals that the four provinces making up the region of Galicia are among the most efficient, confirming the higher performance of local governments located in this region. In contrast, municipalities from La Rioja region show the lowest average efficiency results, followed by the regions of Murcia in 2008 and Aragon in 2013. Efficiency scores considered by provinces again reveal municipalities in La Rioja as having the lowest levels of efficiency, although other provinces such as Cuenca (in Castile La Mancha), Zaragoza (Aragon) or Málaga (Andalusia) also present poor performances in most cases.

The above descriptive analysis gives us an initial insight into the existence of interregional differences, where municipalities with higher or lower levels of efficiency seem to concentrate. In order to statistically support this point, we carry out a Kruskal-Wallis ${ }^{21}$ test to determine whether any of the differences between the medians of the regions (or provinces within each region) are statistically significant. We consider the null hypothesis $H_{0}$ : The $k$ medians for all regions are equal, meaning that there is no statistically significant difference between the median efficiency scores of municipalities located in different regions (or provinces within a region), against the alternative hypothesis $H_{1}$ : At least two regions differ. Results are provided in Table 13. The test results show that differences across regions are significant. However, the differences between provinces are significant depending on the region analysed. For instance, there are differences at the 5\% level of significance for Andalusia or Castile and Leon, while there are no differences for Galicia, which is in line with our findings in the descriptive analysis.

\section{Conclusions}

In recent years, the context of the international economic crisis has prioritised the improvement of public management efficiency in local governments. In most euro-area countries, the economic and financial situation has had a huge impact on many local governments' incomes, leading to increased deficits. Interest in public efficiency is even higher in countries

the possible implications of service quality when measuring local government cost efficiency.) However, qualitative results for output Models 1 and 2 are not greatly different and are available upon request.

${ }^{21}$ Kruskal-Wallis test is the nonparametric alternative to the one-way ANOVA. 
such as Spain, where municipalities have faced stricter budget limitations with the law on budgetary stability (Ley General Presupuestaria), which tightened control over public debt and public spending. Spain has also experienced a deep economic recession since 2008, and came under serious scrutiny within the euro-zone in 2012. In these circumstances, issues related to Spanish local government efficiency and their contribution to public sector deficit are even more relevant. In this paper, we have analysed the overall cost efficiency of Spanish local governments during the period of the economic crisis (2008-2013) which to date has scarcely been examined, and which has had serious effects on Spanish local governments.

Regardless of the context of the analysis, the current large body of literature evaluating local government efficiency shares two important and still unsolved problems. The first is the complexity of defining local governments' outputs and inputs; the second is the lack of a clear standard methodology to measure efficiency. The present study also contributes to fill these gaps by defining several output models and employing four separate non-parametric approaches to estimate local government cost efficiency. The sample included 1,574 Spanish local governments with populations between 1,000 and 50,000 for the period 2008-2013, the widest-ranging sample based on Spanish data used to date.

Our results point to significant differences in the distribution of the efficiency scores between years 2008 and 2013. In general, efficiency scores improved over the years. In the context of economic crisis, Spanish local governments have come under pressure to accommodate severe economic restrictions while still attending to citizen needs. Thus, we conclude that Spanish local governments have improved their efficiency levels since they reduced their budget expenditures (inputs or costs) while maintaining or increasing local public service provision (outputs) over the crisis period 2008-2013.

Moreover, given the problems of defining the bundle of services and facilities that municipalities must provide, we propose three output models including quantity and quality variables. Our results confirm the importance of considering alternative input-output models in order to assess whether the different choices might explain heterogeneity among local governments. Moreover, in our sample of Spanish local governments we find statistical evidence of the possible implications of service quality when measuring local government cost efficiency. There is a trade-off between cost efficiency and service quality when quality variables are accounted for. In this setting, the inclusion of quality variables in efficiency analysis is 
particularly interesting and informative for policy-makers, since performance decisions may have an impact on their quality and not on their quantity.

Another important issue concerns the structural differences in the average cost efficiency between municipalities located in different Spanish regions and provinces. This is the first time that local governments' location in a given territory has been investigated in the local government efficiency literature. We found that municipalities with higher efficiency scores are concentrated in the north of the country, while La Rioja and some of the eastern provinces such as Murcia or Aragon present lower efficiency values. These results suggest that these interregional differences should be considered when public policies and fiscal adjustments are being designed to control local governments' budget expenditures since they could affect equality of access to local public services.

Finally, the comparison of results from the four non-parametric methodologies reveals that efficiency scores can vary widely depending on the method applied (Geys and Moesen, 2009b). Since there is no clear standard methodology to measure efficiency, accurately assessing cost efficiency remains difficult. It therefore makes sense to use a variety of methodologies in order to check the robustness of the results. As expected, local managers have some margin to optimise the use of public resources, suggesting that Spanish municipalities could achieve the same level of local output with fewer resources. We found considerable differences in the mean efficiency scores between the various reference technologies, ranging from 0.44 to 0.96 (also depending on the model and the year). Therefore, in line with previous research our results confirm that the level and variation of the efficiency scores are affected by the approach taken. 


\section{References}

Afonso, A. and Fernandes, S. (2008). Assessing and explaining the relative efficiency of local government. The Journal of Socio-Economics, 37(5):1946-1979.

Almendral, V. R. (2013). The Spanish legal framework for curbing the public debt and the deficit. European Constitutional Law Review, 9(02):189-204.

Andrews, R. and Boyne, G. (2011). Corporate capacity and public service performance. Public Administration, 89(3):894-908.

Bădin, L., Daraio, C., and Simar, L. (2014). Explaining inefficiency in nonparametric production models: the state of the art. Annals of Operations Research, 214(1):5-30.

Badunenko, O., Henderson, D. J., and Kumbhakar, S. C. (2012). When, where and how to perform efficiency estimation. Journal of the Royal Statistical Society: Series A (Statistics in Society), 175(4):863-892.

Balaguer-Coll, M. T. and Prior, D. (2009). Short-and long-term evaluation of efficiency and quality. An application to Spanish municipalities. Applied Economics, 41(23):2991-3002.

Balaguer-Coll, M. T., Prior, D., and Tortosa-Ausina, E. (2007). On the determinants of local government performance: a two-stage nonparametric approach. European Economic Review, 51(2):425-451.

Balaguer-Coll, M. T., Prior, D., and Tortosa-Ausina, E. (2010). Decentralization and efficiency of local government. The Annals of Regional Science, 45(3):571-601.

Balaguer-Coll, M. T., Prior, D., and Tortosa-Ausina, E. (2013). Output complexity, environmental conditions, and the efficiency of municipalities. Journal of Productivity Analysis, 39(3):303324.

Balaguer-Coll, M. T., Prior, D., and Tortosa-Ausina, E. (2016). On the determinants of local government debt: Does one size fit all? International Public Management Journal, 19(4):513542.

Banker, R. D., Charnes, A., and Cooper, W. W. (1984). Some models for estimating technical and scale inefficiencies in Data Envelopment Analysis. Management Science, 30(9):1078-1092. 
Barreiro, B. and Sánchez-Cuenca, I. (2012). In the whirlwind of the economic crisis: local and regional elections in Spain, May 2011. South European Society and Politics, 17(2):281-294.

Bogetoft, P. and Otto, L. (2010). Benchmarking with DEA, SFA, and R, volume 157. Springer Science \& Business Media, New York.

Bosch-Roca, N., Mora-Corral, A. J., and Espasa-Queralt, M. (2012). Citizen control and the efficiency of local public services. Environment and Planning C: Government and Policy, 30(2):248.

Cabasés, F., Pascual, P., and Vallés, J. (2007). The effectiveness of institutional borrowing restrictions: Empirical evidence from Spanish municipalities. Public Choice, 131(3-4):293313.

Cazals, C., Florens, J.-P., and Simar, L. (2002). Nonparametric frontier estimation: a robust approach. Journal of Econometrics, 106(1):1-25.

Charnes, A., Cooper, W. W., and Rhodes, E. (1978). Measuring the efficiency of decision making units. European Journal of Operational Research, 2(6):429-444.

Coelli, T. J., Rao, D. S. P., O’Donnell, C. J., and Battese, G. E. (2005). An Introduction to Efficiency and Productivity Analysis. Springer Science \& Business Media, Heidelberg.

Da Cruz, N. F. and Marques, R. C. (2014). Revisiting the determinants of local government performance. Omega, 44:91-103.

Da Silva, T., Martins-filho, C., Ribeiro, E., et al. (2016). A comparison of nonparametric efficiency estimators: DEA, FDH, DEAC, FDHC, order-m and quantile. Economics Bulletin, 36(1):118-131.

Daraio, C. and Simar, L. (2005). Introducing environmental variables in nonparametric frontier models: a probabilistic approach. Journal of Productivity Analysis, 24(1):93-121.

Daraio, C. and Simar, L. (2007). Advanced Robust and Nonparametric Methods in Efficiency Analysis: Methodology and Applications, volume 4. Springer Science \& Business Media, New York.

De Borger, B. and Kerstens, K. (1996a). Cost efficiency of Belgian local governments: a comparative analysis of FDH, DEA, and econometric approaches. Regional Science and Urban Economics, 26(2):145-170. 
De Borger, B. and Kerstens, K. (1996b). Radial and nonradial measures of technical efficiency: an empirical illustration for Belgian local governments using an FDH reference technology. Journal of Productivity Analysis, 7(1):41-62.

Deprins, D., Simar, L., and Tulkens, H. (1984). The Performance of Public Enterprises: Concepts and Measurements, chapter Measuring labor inefficiency in post offices, pages 243-267. M. Marchand, P. Pestieau and H. Tulkens (eds.), Amsterdam, NorthHolland.

Devas, N. and Delay, S. (2006). Local democracy and the challenges of decentralising the state: An international perspective. Local Government Studies, 32(5):677-695.

Doumpos, M. and Cohen, S. (2014). Applying Data Envelopment Analysis on accounting data to assess and optimize the efficiency of Greek local governments. Omega, 46:74-85.

Färe, R., Grosskopf, S., and Lovell, C. K. (1994). Production Frontiers. Cambridge University Press, Cambridge.

Fogarty, J. and Mugera, A. (2013). Local government efficiency: evidence from Western Australia. Australian Economic Review, 46(3):300-311.

Fried, H. O., Lovell, C. K., and Schmidt, S. S. (2008). The Measurement of Productive Efficiency and Productivity Growth. Oxford University Press, New York.

Geys, B. and Moesen, W. (2009a). Exploring sources of local government technical inefficiency: evidence from Flemish municipalities. Public Finance and Management, 9(1):1-29.

Geys, B. and Moesen, W. (2009b). Measuring local government technical (in)efficiency: an application and comparison of FDH, DEA and econometric approaches. Public Performance and Management Review, 32(4):499-513.

Giménez, V. M. and Prior, D. (2007). Long-and short-term cost efficiency frontier evaluation: evidence from Spanish local governments. Fiscal Studies, 28(1):121-139.

Golany, B. and Roll, Y. (1989). An application procedure for DEA. Omega, 17(3):237-250.

Kalb, A., Geys, B., and Heinemann, F. (2012). Value for money? German local government efficiency in a comparative perspective. Applied Economics, 44(2):201-218. 
Kneip, A., Simar, L., and Wilson, P. W. (2008). Asymptotics and consistent bootstraps for DEA estimators in nonparametric frontier models. Econometric Theory, 24(06):1663-1697.

Li, Q. (1996). Nonparametric testing of closeness between two unknown distribution functions. Econometric Reviews, 15(3):261-274.

Lo Storto, C. (2016). The trade-off between cost efficiency and public service quality: a nonparametric frontier analysis of Italian major municipalities. Cities, 51:52-63.

Martín, J. M. T., Martín, J., de Beaumont Torres, I. F., San Alberto, D. A., and García, A. R. (2011). Los gastos no obligatorios en los municipios de Madrid, Cataluña y Andalucía. Documentos-Instituto de Estudios Fiscales, (25):1.

Méndez Gutiérrez del Valle, R. (2015). Geografía de la Crisis Económica en España [Geography of the Economic Crisis in Spain], chapter Crisis económica y reconfiguraciones territoriales, pages 17-38. Universitat de València, Servei de Publicacions.

Murillo-Zamorano, L. R. (2004). Economic efficiency and frontier techniques. Journal of Economic Surveys, 18(1):33-77.

Narbón-Perpiñá, I. and De Witte, K. (2017a). Local governments' efficiency: a systematic literature review - Part I. International Transactions in Operational Research. In Press. DOI: 10.1111/itor.12364.

Narbón-Perpiñá, I. and De Witte, K. (2017b). Local governments' efficiency: a systematic literature review - Part II. International Transactions in Operational Research. In Press. DOI: 10.1111/itor.12364.

Pastor, J. M. and Tortosa-Ausina, E. (2008). Social capital and bank performance: An international comparison for OECD countries. The Manchester School, 76(2):223-265.

Pérez López, G., Plata Díaz, A. M., Zafra Gómez, J. L., and López Hernández, A. M. (2013).

Deuda viva municipal en un contexto de crisis económica: Análisis de los factores determinantes y de las formas de gestión. Revista de Contabilidad, 16(2):83-93.

Pérez-López, G., Prior, D., and Zafra-Gómez, J. L. (2015). Rethinking New Public Management delivery forms and efficiency: long-term effects in Spanish local government. Journal of Public Administration Research and Theory, 25(4):1157-1183. 
Portillo Navarro, M. J. (2009). La situación presupuestaria de los municipios españoles a través de sus indicadores (1992-2008). Especial referencia al indicador de rigidez del gasto corriente. Presupuesto y Gasto Público, (57):117-134.

Sampaio de Sousa, M. C. and Stošić, B. (2005). Technical efficiency of the Brazilian municipalities: correcting nonparametric frontier measurements for outliers. Journal of Productivity Analysis, 24(2):157-181.

Simar, L. and Wilson, P. W. (1998). Sensitivity analysis of efficiency scores: how to bootstrap in nonparametric frontier models. Management Science, 44(1):49-61.

Simar, L. and Wilson, P. W. (2000). Statistical inference in nonparametric frontier models: the state of the art. Journal of Productivity Analysis, 13(1):49-78.

Simar, L. and Wilson, P. W. (2008). Statistical inference in nonparametric frontier models: recent developments and perspectives. The Measurement of Productive Efficiency (H. Fried, CAK Lovell and SS Schmidt Eds), Oxford University Press, Oxford, pages 421-521.

Simar, L. and Zelenyuk, V. (2006). On testing equality of distributions of technical efficiency scores. Econometric Reviews, 25(4):497-522.

Štastná, L. and Gregor, M. (2015). Public sector efficiency in transition and beyond: evidence from Czech local governments. Applied Economics, 47(7):680-699.

Vilalta Ferrer, M. (2010). Los servicios prestados por los municipios españoles: una aproximación a través del análisis de su presupuesto de gastos. In Colección documentos e informes Fundación Democracia y Gobierno Local, pages 97-128. Fundación Democracia y Gobierno Local.

Zafra-Gómez, J. L. and Muñiz-Pérez, Antonio, M. (2010). Overcoming cost-inefficiencies within small municipalities: improve financial condition or reduce the quality of public services? Environment and Planning C: Government and Policy, 28(4):609-629. 
Table 1: Distribution of total public expenditures among central, regional and local administrations (\%)

\begin{tabular}{lrrrr}
\hline & 1995 & 2000 & 2005 & 2010 \\
\hline Central & 62.05 & 53.81 & 46.31 & 45.68 \\
Regional & 24.19 & 30.91 & 38.22 & 38.60 \\
Local & 13.76 & 15.28 & 15.48 & 15.72 \\
\hline Total & 100.00 & 100.00 & 100.00 & 100.00 \\
\hline
\end{tabular}

Source: IGAE, Ministry of the Treasury and Public Administrations (IGAE, Ministerio de Hacienda y Administraciones Públicas). 
Table 2: Structure of local revenues during the period 2008-2013 (\%)

\begin{tabular}{|c|c|c|}
\hline & & Revenues $^{\mathrm{a}}(\%)$ \\
\hline Current revenues & & 81.09 \\
\hline \multirow[t]{6}{*}{ Direct taxes } & & 32.23 \\
\hline & Property tax ${ }^{b}$ & 21.32 \\
\hline & Motor Vehicle tax ${ }^{c}$ & 4.48 \\
\hline & Tax on the Increase in the Value of Urban Land ${ }^{\mathrm{d}}$ & 2.77 \\
\hline & Tax on Business Activities ${ }^{\mathrm{e}}$ & 2.80 \\
\hline & Other direct taxes & 0.86 \\
\hline \multirow[t]{3}{*}{ Indirect taxes } & & 2.39 \\
\hline & Tax on Construction, Installations and other Works $\mathrm{f}$ & 1.60 \\
\hline & Other indirect taxes & 0.79 \\
\hline \multirow[t]{4}{*}{ Fees and other revenues } & & 16.14 \\
\hline & Fees & 10.35 \\
\hline & Public fares & 1.15 \\
\hline & Other revenues & 4.64 \\
\hline \multirow[t]{5}{*}{ Current grants received } & & 28.05 \\
\hline & From central government & 17.59 \\
\hline & From regional government & 6.79 \\
\hline & From provincial council (Diputaciones) & 2.91 \\
\hline & Other grants & 0.75 \\
\hline Property incomes & & 2.28 \\
\hline \multirow[t]{3}{*}{ Capital revenues } & & 11.00 \\
\hline & Sale of fixed assets & 1.03 \\
\hline & Capital transfers & 9.98 \\
\hline Non-financial revenues & & 92.09 \\
\hline Financial revenues & & 7.91 \\
\hline Total revenues & & 100.00 \\
\hline
\end{tabular}

Sources: Data from Ministry of the Treasury and Public Administrations (Ministerio de Hacienda y Administraciones Públicas).

a Share of total revenues averaged over the period 2008-2013.

$\mathrm{b}$ IBI, Impuesto de Bienes Inmuebles.

c IVTM, Impuesto sobre Vehículos de Tracción Mecánica.

d IIVTNU, Impuesto sobre el Incremento de Valor de los Terrenos de Naturaleza Urbana.

e IAE, Impuesto de Actividades Económicas.

${ }_{\mathrm{f}}^{\mathrm{ICIO}}$, Impuesto sobre Construcciones, Instalaciones y Obras. 


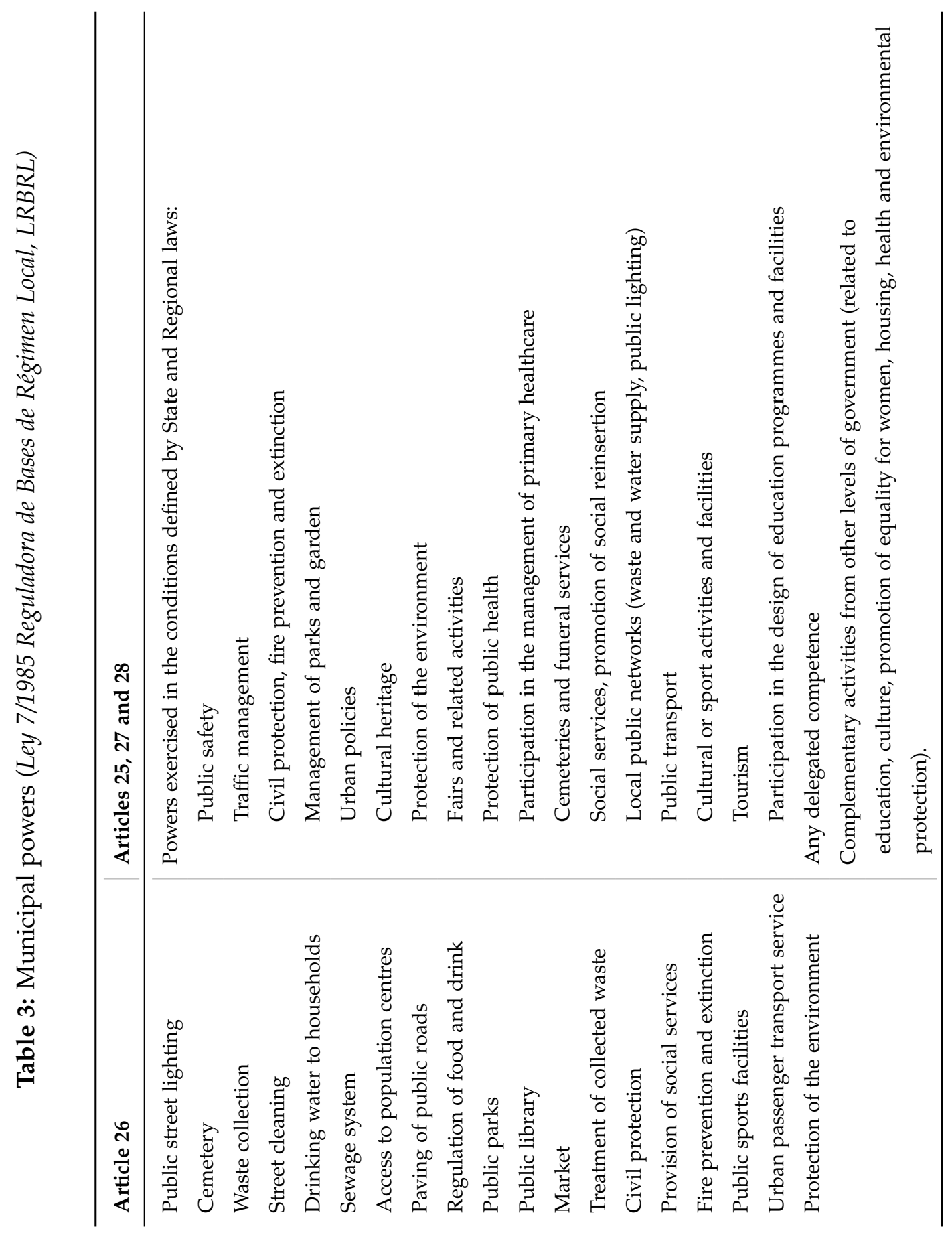


Table 4: Distribution of the sample, Spanish regions (Comunidades Autónomas)

\begin{tabular}{lr}
\hline Region & Number of municipalities \\
\hline Andalusia & 378 \\
Aragon & 58 \\
Asturias & 42 \\
Balearic Islands & 48 \\
Canary Islands & 46 \\
Cantabria & 45 \\
Castile and Leon & 139 \\
Castile La Mancha & 170 \\
Extremadura & 116 \\
Galicia & 211 \\
Murcia & 28 \\
La Rioja & 24 \\
Valencian Community & 269 \\
\hline Total & 1,574 \\
\hline
\end{tabular}




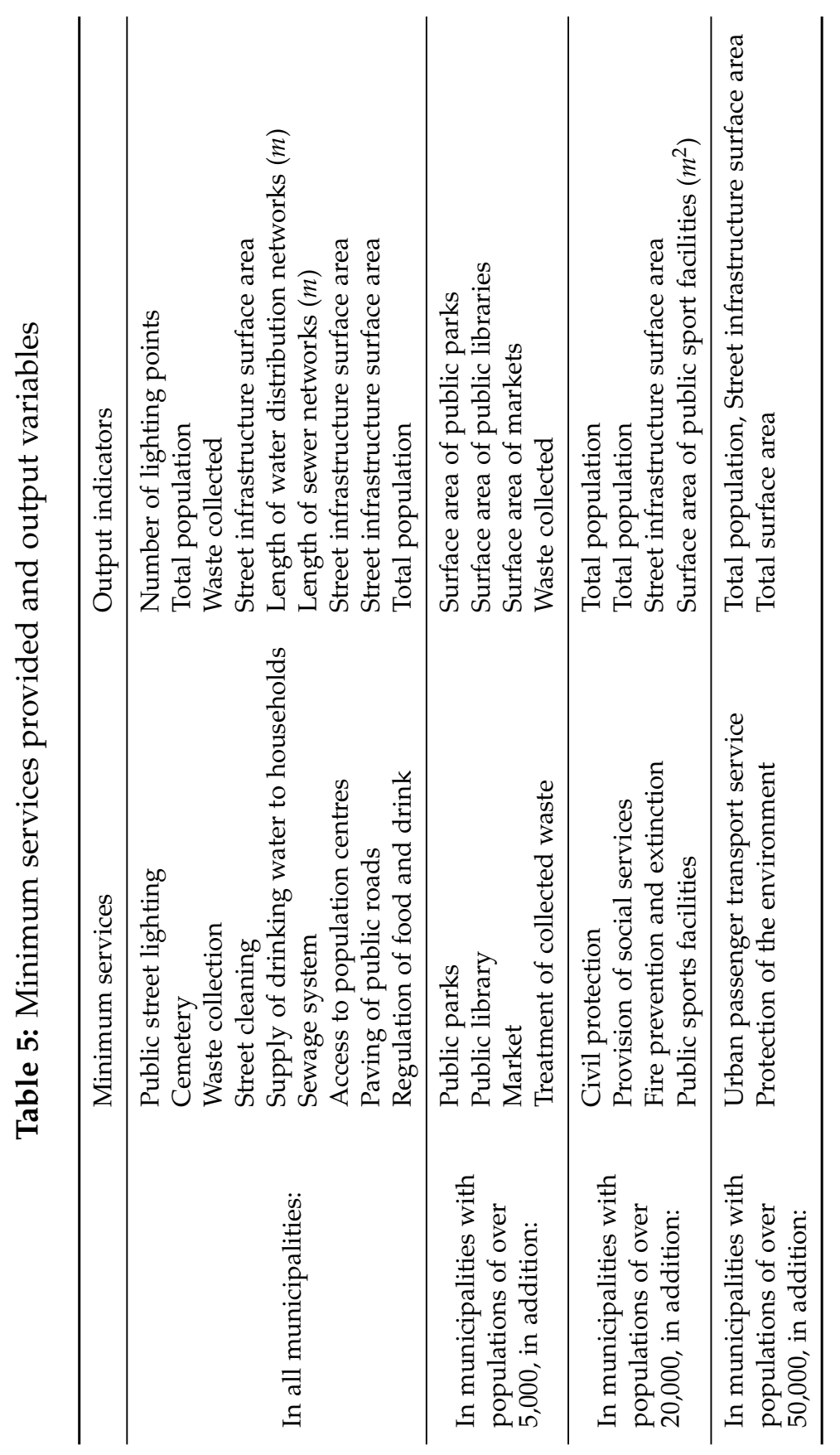


Table 6: Descriptive statistics for inputs and outputs (20082013)

\begin{tabular}{lrr}
\hline & Mean & S.d. \\
\hline Inputs $^{\mathrm{a}}$ & & \\
\hline Total costs $\left(X_{1}\right)$ & $6,856,864.55$ & $7,990,865.20$ \\
\hline Outputs & & \\
\hline Total population $\left(Y_{1}\right)$ & $7,555.36$ & $8,460.33$ \\
Street infrastructure surface area $\mathrm{b}\left(Y_{2}\right)$ & $336,673.55$ & $325,808.07$ \\
Number of lighting points $\left(Y_{3}\right)$ & $1,519.78$ & $1,567.02$ \\
Tons of waste collected $\left(Y_{4}\right)$ & $4,216.73$ & $19,720.07$ \\
Length of water distribution networks $\mathrm{b}\left(Y_{5}\right)$ & $50,503.12$ & $93,877.89$ \\
Length of sewer networks $\mathrm{b}\left(Y_{6}\right)$ & $29,650.29$ & $32,424.83$ \\
Public parks surface area ${ }^{(}\left(Y_{7}\right)$ & $88,339.98$ & $565,984.51$ \\
Public library surface area ${ }^{b}\left(Y_{8}\right)$ & 361.38 & $1,751.10$ \\
Market surface $\operatorname{area}^{\mathrm{b}}\left(Y_{9}\right)$ & $90,746.34$ & $502,781.06$ \\
Sport facilities surface $\operatorname{area}^{\mathrm{b}}\left(Y_{10}\right)$ & $3,959.79$ & $10,752.72$ \\
\hline
\end{tabular}

${ }^{\mathrm{a}}$ In thousands of euros.

${ }^{\mathrm{b}}$ In square metres. 
Table 7: Summary statistics for efficiency results, Model $1^{\text {a }}$

\begin{tabular}{|c|c|c|c|c|c|c|}
\hline \multicolumn{7}{|c|}{ DEA estimator } \\
\hline Year & Mean & Median & Min & Max & S.d. & $\begin{array}{l}\% \text { of efficient } \\
\text { municipalities }\end{array}$ \\
\hline 2008 & 0.4943 & 0.4689 & 0.0437 & 1.0000 & 0.1876 & 2.6048 \\
\hline 2009 & 0.5843 & 0.5740 & 0.1257 & 1.0000 & 0.1677 & 2.6684 \\
\hline 2010 & 0.5212 & 0.4953 & 0.1312 & 1.0000 & 0.1718 & 1.9695 \\
\hline 2011 & 0.5314 & 0.5092 & 0.1359 & 1.0000 & 0.1728 & 1.9060 \\
\hline 2012 & 0.5316 & 0.5128 & 0.1079 & 1.0000 & 0.1749 & 1.8424 \\
\hline 2013 & 0.5712 & 0.5591 & 0.1138 & 1.0000 & 0.1817 & 2.7954 \\
\hline \multicolumn{7}{|c|}{ FDH estimator } \\
\hline Year & Mean & Median & Min & Max & S.d. & $\begin{array}{l}\% \text { of efficient } \\
\text { municipalities }\end{array}$ \\
\hline 2008 & 0.7444 & 0.7678 & 0.0808 & 1.0000 & 0.2276 & 27.0013 \\
\hline 2009 & 0.8186 & 0.8563 & 0.2045 & 1.0000 & 0.1841 & 32.8463 \\
\hline 2010 & 0.7761 & 0.7848 & 0.1559 & 1.0000 & 0.1961 & 26.1753 \\
\hline 2011 & 0.7453 & 0.7434 & 0.2037 & 1.0000 & 0.2108 & 24.3329 \\
\hline 2012 & 0.7630 & 0.7737 & 0.1497 & 1.0000 & 0.2076 & 25.4765 \\
\hline 2013 & 0.7619 & 0.7721 & 0.1497 & 1.0000 & 0.2055 & 25.0318 \\
\hline \multicolumn{7}{|c|}{ Order- $m$ estimator } \\
\hline Year & Mean & Median & Min & Max & S.d. & $\begin{array}{c}\% \text { of efficient } \\
\text { municipalities }\end{array}$ \\
\hline 2008 & 0.8089 & 0.8255 & 0.0834 & 1.9813 & 0.2353 & 29.4155 \\
\hline 2009 & 0.8691 & 0.8926 & 0.2122 & 1.7369 & 0.2005 & 36.4041 \\
\hline 2010 & 0.8385 & 0.8515 & 0.2172 & 1.8080 & 0.2032 & 29.6061 \\
\hline 2011 & 0.8088 & 0.8100 & 0.2368 & 2.0281 & 0.2197 & 27.5731 \\
\hline 2012 & 0.8222 & 0.8358 & 0.1797 & 1.8914 & 0.2169 & 29.2884 \\
\hline 2013 & 0.8209 & 0.8328 & 0.1785 & 1.9204 & 0.2175 & 28.7802 \\
\hline \multicolumn{7}{|c|}{ KSW estimator } \\
\hline Year & Mean & Median & Min & Max & S.d. & $\begin{array}{l}\% \text { of efficient } \\
\text { municipalities }\end{array}$ \\
\hline 2008 & 0.4421 & 0.4239 & 0.0400 & 1.0000 & 0.1720 & 0.0000 \\
\hline 2009 & 0.5383 & 0.5300 & 0.1179 & 1.0000 & 0.1575 & 0.0000 \\
\hline 2010 & 0.4541 & 0.4296 & 0.0563 & 1.0000 & 0.1602 & 0.0669 \\
\hline 2011 & 0.4752 & 0.4558 & 0.1178 & 1.0000 & 0.1572 & 0.0000 \\
\hline 2012 & 0.4677 & 0.4477 & 0.0134 & 1.0000 & 0.1650 & 0.0000 \\
\hline 2013 & 0.4846 & 0.4709 & 0.0118 & 1.0000 & 0.1617 & 0.0669 \\
\hline
\end{tabular}

a This model includes minimum services compulsory for all governments (6 outputs variables from $Y_{1}$ to $\left.Y_{6}\right)$. 
Table 8: Summary statistics for efficiency results, Model $2^{\mathrm{a}}$

\begin{tabular}{|c|c|c|c|c|c|c|}
\hline \multicolumn{7}{|c|}{ DEA estimator } \\
\hline Year & Mean & Median & Min & Max & S.d. & $\begin{array}{l}\text { \% of efficient } \\
\text { municipalities }\end{array}$ \\
\hline 2008 & 0.5125 & 0.4839 & 0.0446 & 1.0000 & 0.1968 & 2.7954 \\
\hline 2009 & 0.5957 & 0.5829 & 0.1268 & 1.0000 & 0.1740 & 3.9390 \\
\hline 2010 & 0.5382 & 0.5102 & 0.1421 & 1.0000 & 0.1806 & 3.1131 \\
\hline 2011 & 0.5506 & 0.5237 & 0.1359 & 1.0000 & 0.1815 & 3.2402 \\
\hline 2012 & 0.5528 & 0.5339 & 0.1269 & 1.0000 & 0.1842 & 3.1131 \\
\hline 2013 & 0.5900 & 0.5757 & 0.1299 & 1.0000 & 0.1884 & 4.7014 \\
\hline \multicolumn{7}{|c|}{ FDH estimator } \\
\hline Year & Mean & Median & Min & Max & S.d. & $\begin{array}{l}\% \text { of efficient } \\
\text { municipalities }\end{array}$ \\
\hline 2008 & 0.8900 & 1.0000 & 0.0945 & 1.0000 & 0.1795 & 61.8170 \\
\hline 2009 & 0.9251 & 1.0000 & 0.3233 & 1.0000 & 0.1394 & 66.4549 \\
\hline 2010 & 0.9112 & 1.0000 & 0.3040 & 1.0000 & 0.1524 & 63.2783 \\
\hline 2011 & 0.8923 & 1.0000 & 0.2428 & 1.0000 & 0.1755 & 61.8170 \\
\hline 2012 & 0.8957 & 1.0000 & 0.2724 & 1.0000 & 0.1684 & 60.6734 \\
\hline 2013 & 0.9023 & 1.0000 & 0.2648 & 1.0000 & 0.1594 & 61.3723 \\
\hline \multicolumn{7}{|c|}{ Order- $m$ estimator } \\
\hline Year & Mean & Median & Min & Max & S.d. & $\begin{array}{l}\% \text { of efficient } \\
\text { municipalities }\end{array}$ \\
\hline 2008 & 0.9238 & 1.0000 & 0.0969 & 1.8544 & 0.1903 & 63.0241 \\
\hline 2009 & 0.9606 & 1.0000 & 0.3420 & 1.7793 & 0.1541 & 68.8691 \\
\hline 2010 & 0.9501 & 1.0000 & 0.3130 & 2.0046 & 0.1657 & 65.2478 \\
\hline 2011 & 0.9376 & 1.0000 & 0.2800 & 2.2371 & 0.1874 & 63.9136 \\
\hline 2012 & 0.9364 & 1.0000 & 0.2946 & 2.3782 & 0.1823 & 63.0877 \\
\hline 2013 & 0.9439 & 1.0000 & 0.2937 & 2.4632 & 0.1813 & 63.7230 \\
\hline \multicolumn{7}{|c|}{ KSW estimator } \\
\hline Year & Mean & Median & Min & Max & S.d. & $\begin{array}{l}\% \text { of efficient } \\
\text { municipalities }\end{array}$ \\
\hline 2008 & 0.4462 & 0.4246 & 0.0310 & 1.0000 & 0.1797 & 0.0000 \\
\hline 2009 & 0.5333 & 0.5250 & 0.1044 & 1.0000 & 0.1618 & 0.0000 \\
\hline 2010 & 0.4562 & 0.4270 & 0.0373 & 1.0000 & 0.1692 & 0.0000 \\
\hline 2011 & 0.4815 & 0.4603 & 0.1163 & 1.0000 & 0.1644 & 0.0000 \\
\hline 2012 & 0.4775 & 0.4593 & 0.0013 & 1.0000 & 0.1739 & 0.1271 \\
\hline 2013 & 0.5318 & 0.5198 & 0.0982 & 1.0000 & 0.1782 & 0.0669 \\
\hline
\end{tabular}

a This model includes minimum services compulsory for all governments and additional services that must be provided by larger municipalities with populations of over 5,000 and 20,000 (10 output variables from $Y_{1}$ to $Y_{10}$ ). 
Table 9: Summary statistics for efficiency results, Model $3^{\text {a }}$

\begin{tabular}{|c|c|c|c|c|c|c|}
\hline \multicolumn{7}{|c|}{ DEA estimator } \\
\hline Year & Mean & Median & Min & Max & S.d. & $\begin{array}{l}\% \text { of efficient } \\
\text { municipalities }\end{array}$ \\
\hline 2008 & 0.6867 & 0.6780 & 0.0614 & 1.0000 & 0.2651 & 28.6531 \\
\hline 2009 & 0.7469 & 0.7504 & 0.0925 & 1.0000 & 0.2287 & 30.3685 \\
\hline 2010 & 0.7152 & 0.6970 & 0.1141 & 1.0000 & 0.2333 & 27.5731 \\
\hline 2011 & 0.7023 & 0.6680 & 0.1257 & 1.0000 & 0.2379 & 26.4295 \\
\hline 2012 & 0.7101 & 0.7016 & 0.1073 & 1.0000 & 0.2395 & 27.2554 \\
\hline 2013 & 0.7164 & 0.7153 & 0.1043 & 1.0000 & 0.2349 & 26.5565 \\
\hline \multicolumn{7}{|c|}{ FDH estimator } \\
\hline Year & Mean & Median & Min & Max & S.d. & $\begin{array}{l}\% \text { of efficient } \\
\text { municipalities }\end{array}$ \\
\hline 2008 & 0.9210 & 1.0000 & 0.2655 & 1.0000 & 0.1515 & 69.6950 \\
\hline 2009 & 0.9285 & 1.0000 & 0.2655 & 1.0000 & 0.1471 & 72.4269 \\
\hline 2010 & 0.9291 & 1.0000 & 0.2648 & 1.0000 & 0.1429 & 71.3469 \\
\hline 2011 & 0.9230 & 1.0000 & 0.2648 & 1.0000 & 0.1485 & 68.8691 \\
\hline 2012 & 0.9212 & 1.0000 & 0.2385 & 1.0000 & 0.1515 & 68.4879 \\
\hline 2013 & 0.9226 & 1.0000 & 0.2188 & 1.0000 & 0.1478 & 68.6785 \\
\hline \multicolumn{7}{|c|}{ Order- $m$ estimator } \\
\hline Year & Mean & Median & Min & Max & S.d. & $\begin{array}{l}\% \text { of efficient } \\
\text { municipalities }\end{array}$ \\
\hline 2008 & 0.9277 & 1.0000 & 0.2676 & 1.3837 & 0.1502 & 70.0127 \\
\hline 2009 & 0.9375 & 1.0000 & 0.2677 & 1.4062 & 0.1474 & 72.9352 \\
\hline 2010 & 0.9388 & 1.0000 & 0.2648 & 1.8670 & 0.1454 & 71.6010 \\
\hline 2011 & 0.9334 & 1.0000 & 0.2648 & 2.0400 & 0.1506 & 69.4409 \\
\hline 2012 & 0.9315 & 1.0000 & 0.2526 & 1.7124 & 0.1507 & 69.2503 \\
\hline 2013 & 0.9339 & 1.0000 & 0.2335 & 1.6945 & 0.1503 & 69.6315 \\
\hline \multicolumn{7}{|c|}{ KSW estimator } \\
\hline Year & Mean & Median & Min & Max & S.d. & $\begin{array}{l}\% \text { of efficient } \\
\text { municipalities }\end{array}$ \\
\hline 2008 & 0.5913 & 0.5608 & 0.0017 & 1.0000 & 0.2558 & 0.0000 \\
\hline 2009 & 0.5911 & 0.5641 & 0.0351 & 1.0000 & 0.2492 & 0.0000 \\
\hline 2010 & 0.6007 & 0.5649 & 0.0466 & 1.0000 & 0.2410 & 0.0000 \\
\hline 2011 & 0.6144 & 0.5748 & 0.0193 & 1.0000 & 0.2350 & 0.0635 \\
\hline 2012 & 0.6146 & 0.5848 & 0.0295 & 1.0000 & 0.2352 & 0.0635 \\
\hline 2013 & 0.6085 & 0.5783 & 0.0000 & 1.0000 & 0.2311 & 0.0669 \\
\hline
\end{tabular}

a This model includes minimum services compulsory for all governments and additional services that must be provided by larger municipalities with populations of over 5,000 and 20,000 taking into account service quality (10 output variables from $Y_{1}$ to $Y_{10}$ weighted by their quality). 
Table 10: Effect of including the quality of services based on comparing distributions (Li's (1996) test with the variation proposed by Simar and Zelenyuk (2006))

This table reports results on the significance of the differences between the distribution of the efficiency levels for Models 2 and 3, which differ in their inclusion of service quality. We test the null hypothesis $H_{0}: f($ Model2) $=$ $g($ Model3) (i.e., the distribution of the efficiency scores in Model 2 is equal to the distribution of the efficiency scores in Model 3), against the alternative $H_{1}: f($ Model2 $) \neq g($ Model3).

\begin{tabular}{lrr}
\hline Estimator & Year & T-statistic $(p$-value) \\
\hline DEA & 2008 & $231.2601\left(0.0000^{*}\right)$ \\
& 2009 & $256.6770\left(0.0000^{*}\right)$ \\
& 2010 & $237.7093\left(0.0000^{*}\right)$ \\
& 2011 & $189.2445\left(0.0000^{*}\right)$ \\
& 2012 & $204.9543\left(0.0000^{*}\right)$ \\
& 2013 & $157.1427\left(0.0000^{*}\right)$ \\
\hline FDH & 2008 & $6.1007\left(0.0000^{*}\right)$ \\
& 2009 & $2.2549\left(0.0340^{*}\right)$ \\
& 2010 & $6.4186\left(0.0000^{*}\right)$ \\
& 2011 & $4.8774\left(0.0030^{*}\right)$ \\
& 2012 & $3.9812\left(0.0050^{*}\right)$ \\
& 2013 & $4.0908\left(0.0020^{*}\right)$ \\
\hline Order- $m$ & 2008 & $4.4787\left(0.0020^{*}\right)$ \\
& 2009 & $4.4153\left(0.0020^{*}\right)$ \\
& 2010 & $2.4271\left(0.0100^{*}\right)$ \\
& 2011 & $2.8296\left(0.0230^{*}\right)$ \\
& 2012 & $2.5501\left(0.0230^{*}\right)$ \\
& 2013 & $1.9678\left(0.0350^{*}\right)$ \\
\hline KSW & 2008 & $144.1003\left(0.0000^{*}\right)$ \\
& 2009 & $86.4735\left(0.0000^{*}\right)$ \\
& 2010 & $140.9611\left(0.0000^{*}\right)$ \\
& 2011 & $118.0488\left(0.0000^{*}\right)$ \\
& 2012 & $111.1173\left(0.0000^{*}\right)$ \\
& 2013 & $45.8914\left(0.0000^{*}\right)$ \\
\hline \multirow{6}{*}{. } & &
\end{tabular}

* denotes differences are significant at the $5 \%$ level. 
Table 11: Comparing efficiency over time (2008 vs. 2013) based on Li's (1996) test with the variation proposed by Simar and Zelenyuk (2006)

We test whether the differences between the distribution of the efficiency levels in 2008 and 2013 are significant. We test the null hypothesis $H_{0}: f(2008)=g(2013)$ (i.e., the distribution of the efficiency scores in the initial year, 2008, is equal to the distribution of the efficiency scores in the final year, 2013), against the alternative $H_{1}: f(2008) \neq g(2013)$.

\begin{tabular}{lcrl}
\hline Estimator & Model & $T$-statistic & $p$-value \\
\hline DEA & Model 1 & 66.4750 & $0.0000^{*}$ \\
& Model 2 & 66.5180 & $0.0000^{*}$ \\
& Model 3 & 16.2057 & $0.0000^{*}$ \\
\hline FDH & Model 1 & 6.0456 & $0.0000^{*}$ \\
& Model 2 & 1.9279 & $0.0480^{*}$ \\
& Model 3 & 1.1068 & 0.1560 \\
\hline Order- $m$ & Model 1 & 2.3448 & $0.0480^{*}$ \\
& Model 2 & 0.8743 & 0.2920 \\
& Model 3 & 0.7925 & 0.3290 \\
\hline KSW & Model 1 & 79.9386 & $0.0000^{*}$ \\
& Model 2 & 80.5064 & $0.0000^{*}$ \\
& Model 3 & 4.9732 & $0.0000^{*}$ \\
\hline
\end{tabular}

* denotes differences are significant at the $5 \%$ level. 
Table 12: Distribution of the efficiency scores grouped by Regions and Provinces

This table reports the distribution of the efficiency results classified by regions and provinces for the years 2008 and 2013 in output Model 3.

\begin{tabular}{|c|c|c|c|c|c|c|c|c|}
\hline \multirow[b]{2}{*}{ Territory } & \multicolumn{2}{|c|}{ DEA } & \multicolumn{2}{|c|}{ FDH } & \multicolumn{2}{|c|}{ Order $-m$} & \multicolumn{2}{|c|}{ KSW } \\
\hline & 2008 & 2013 & 2008 & 2013 & 2008 & 2013 & 2008 & 2013 \\
\hline Almería & 0.7079 & 0.7347 & 0.9369 & 0.9362 & 0.9393 & 0.9400 & 0.6003 & 0.6116 \\
\hline Cádiz & 0.8572 & 0.7424 & 1.0000 & 0.9578 & 1.0000 & 0.9582 & 0.7548 & 0.6655 \\
\hline Córdoba & 0.6754 & 0.6350 & 0.9636 & 0.9066 & 0.9666 & 0.9136 & 0.5289 & 0.5616 \\
\hline Granada & 0.7028 & 0.7113 & 0.9140 & 0.9427 & 0.9210 & 0.9470 & 0.5440 & 0.5916 \\
\hline Jaén & 0.6538 & 0.5885 & 0.9270 & 0.8890 & 0.9281 & 0.8930 & 0.4869 & 0.5157 \\
\hline Málaga & 0.6048 & 0.5852 & 0.8331 & 0.8323 & 0.8353 & 0.8373 & 0.5597 & 0.5140 \\
\hline Sevilla & 0.7321 & 0.7518 & 0.9299 & 0.9509 & 0.9304 & 0.9456 & 0.5654 & 0.6442 \\
\hline Andalusia & 0.6977 & 0.6815 & 0.9243 & 0.9184 & 0.9271 & 0.9210 & 0.5632 & 0.5858 \\
\hline Teruel & 0.6065 & 0.6450 & 0.9205 & 0.8814 & 0.9333 & 0.9019 & 0.5782 & 0.5197 \\
\hline Zaragoza & 0.5892 & 0.5918 & 0.8962 & 0.8253 & 0.9007 & 0.8330 & 0.5115 & 0.5192 \\
\hline Aragon & 0.5927 & 0.6029 & 0.9012 & 0.8369 & 0.9074 & 0.8472 & 0.5253 & 0.5193 \\
\hline Asturias & 0.7222 & 0.7580 & 0.9551 & 0.9552 & 0.9617 & 0.9671 & 0.5646 & 0.5347 \\
\hline Balearic Islands & 0.7008 & 0.6577 & 0.8928 & 0.8600 & 0.8950 & 0.8656 & 0.5907 & 0.5820 \\
\hline Las Palmas & 0.5751 & 0.7979 & 0.9144 & 0.9595 & 0.9144 & 0.9595 & 0.4377 & 0.6796 \\
\hline S.C. de Tenerife & 0.5800 & 0.6217 & 0.9306 & 0.8695 & 0.9317 & 0.8637 & 0.5609 & 0.5571 \\
\hline Canary Islands & 0.5783 & 0.6830 & 0.9250 & 0.9008 & 0.9257 & 0.8970 & 0.5180 & 0.5997 \\
\hline Cantabria & 0.7680 & 0.8346 & 0.9532 & 0.9639 & 0.9583 & 0.9694 & 0.4285 & 0.4547 \\
\hline Ávila & 0.7509 & 0.7555 & 0.9221 & 0.9452 & 0.9225 & 0.9487 & 0.5566 & 0.6100 \\
\hline León & 0.7386 & 0.7416 & 0.9374 & 0.9443 & 0.9719 & 1.0461 & 0.4687 & 0.6006 \\
\hline Palencia & 0.5371 & 0.6773 & 0.9188 & 0.8378 & 0.9188 & 0.8378 & 0.5403 & 0.6033 \\
\hline Salamanca & 0.6431 & 0.6929 & 0.8366 & 0.8708 & 0.8558 & 0.9020 & 0.5436 & 0.6044 \\
\hline Segovia & 0.7040 & 0.7998 & 0.9446 & 0.9917 & 0.9647 & 0.9997 & 0.6749 & 0.7306 \\
\hline Soria & 0.7170 & 0.6205 & 0.8762 & 0.8412 & 0.8762 & 0.9139 & 0.5897 & 0.5447 \\
\hline Valladolid & 0.6778 & 0.7287 & 0.9709 & 0.9358 & 0.9922 & 0.9612 & 0.5438 & 0.6166 \\
\hline Zamora & 0.7457 & 0.7054 & 0.9362 & 0.9442 & 0.9983 & 0.9893 & 0.5781 & 0.2801 \\
\hline Castile and Leon & 0.7045 & 0.7273 & 0.9307 & 0.9297 & 0.9555 & 0.9761 & 0.5411 & 0.5815 \\
\hline Albacete & 0.5303 & 0.6839 & 0.9121 & 0.9145 & 0.9223 & 0.9403 & 0.5297 & 0.5313 \\
\hline Ciudad Real & 0.6782 & 0.7051 & 0.8774 & 0.9047 & 0.8834 & 0.9214 & 0.5228 & 0.5902 \\
\hline Cuenca & 0.5566 & 0.6162 & 0.8185 & 0.8350 & 0.8235 & 0.8417 & 0.6111 & 0.5667 \\
\hline Toledo & 0.6917 & 0.7346 & 0.9594 & 0.9499 & 0.9649 & 0.9516 & 0.6070 & 0.6261 \\
\hline Castile La Mancha & 0.6383 & 0.7027 & 0.9125 & 0.9177 & 0.9191 & 0.9288 & 0.5703 & 0.5902 \\
\hline Badajoz & 0.6646 & 0.6972 & 0.9429 & 0.9521 & 0.9532 & 0.9625 & 0.5527 & 0.5186 \\
\hline Cáceres & 0.5999 & 0.6196 & 0.8149 & 0.8544 & 0.8275 & 0.8706 & 0.5462 & 0.5532 \\
\hline Extremadura & 0.6406 & 0.6684 & 0.8954 & 0.9159 & 0.9066 & 0.9284 & 0.5503 & 0.5315 \\
\hline A Coruña & 0.9140 & 0.8517 & 0.9915 & 0.9874 & 0.9919 & 0.9892 & 0.7502 & 0.7022 \\
\hline Lugo & 0.9112 & 0.8064 & 0.9948 & 0.9789 & 1.0009 & 0.9926 & 0.4936 & 0.5997 \\
\hline Orense & 0.8606 & 0.8942 & 0.9708 & 0.9721 & 0.9717 & 0.9877 & 0.6660 & 0.5446 \\
\hline Pontevedra & 0.9183 & 0.8976 & 0.9745 & 0.9903 & 0.9745 & 0.9948 & 0.7385 & 0.7032 \\
\hline Galicia & 0.8987 & 0.8686 & 0.9818 & 0.9823 & 0.9831 & 0.9905 & 0.6859 & 0.6408 \\
\hline Murcia & 0.5194 & 0.6615 & 0.8585 & 0.8706 & 0.8590 & 0.8716 & 0.5014 & 0.5734 \\
\hline La Rioja & 0.5135 & 0.5557 & 0.8021 & 0.8108 & 0.8129 & 0.8291 & 0.5211 & 0.5042 \\
\hline Alicant & 0.6717 & 0.7727 & 0.9313 & 0.9522 & 0.9357 & 0.9601 & 0.6085 & 0.6600 \\
\hline Castellón & 0.5988 & 0.6874 & 0.8469 & 0.9296 & 0.8672 & 0.9489 & 0.5702 & 0.6039 \\
\hline Valencia & 0.5569 & 0.6701 & 0.8890 & 0.9027 & 0.8951 & 0.9162 & 0.5304 & 0.5888 \\
\hline Valencian Community & 0.5961 & 0.7023 & 0.8953 & 0.9209 & 0.9029 & 0.9335 & 0.5586 & 0.6116 \\
\hline
\end{tabular}

Notes: In our final sample there was no information available for the full period 2008 to 2013 for the Basque Country, Navarre, Catalonia and Madrid regions and the provinces of Burgos, Huesca, Guadalajara and Huelva. 


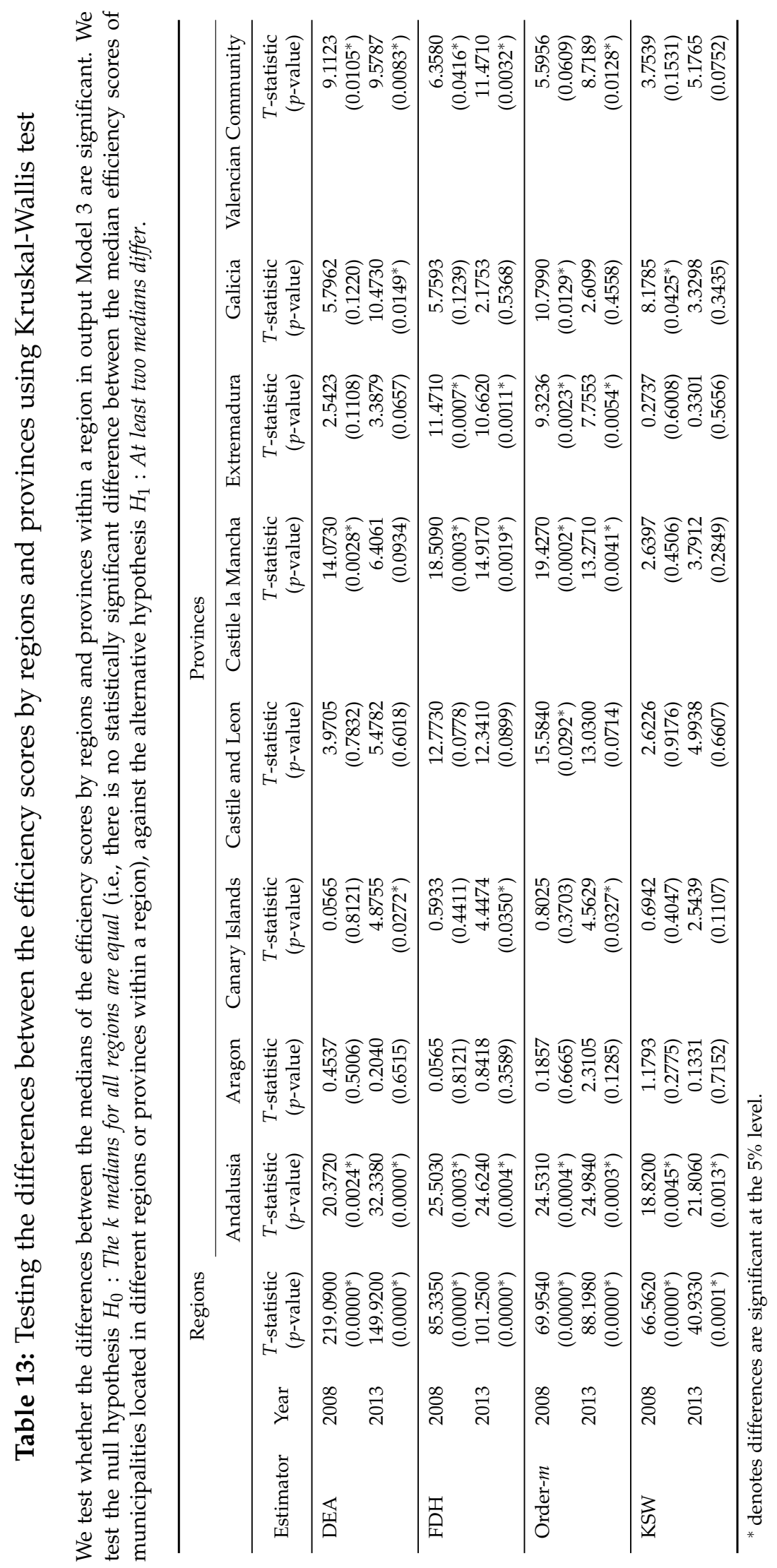


Figure 1: Violin plots for DEA and FDH efficiency scores, the three models per year.

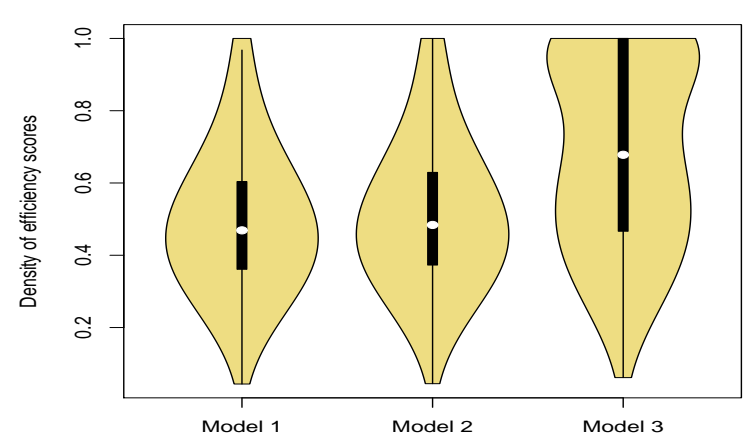

(a) DEA 2008



(c) DEA 2009-2012

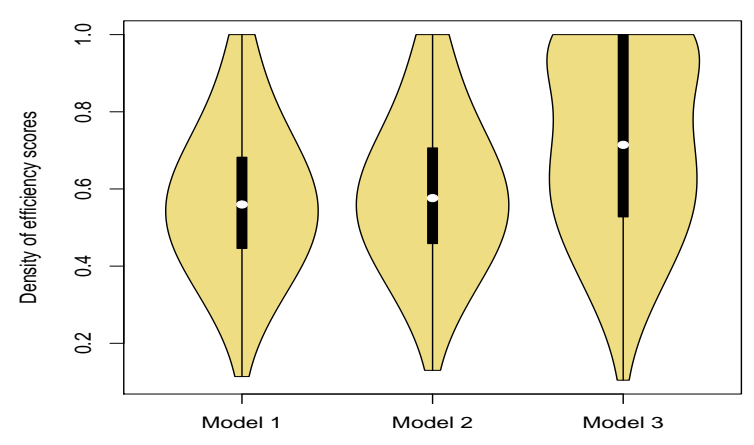

(e) DEA 2013

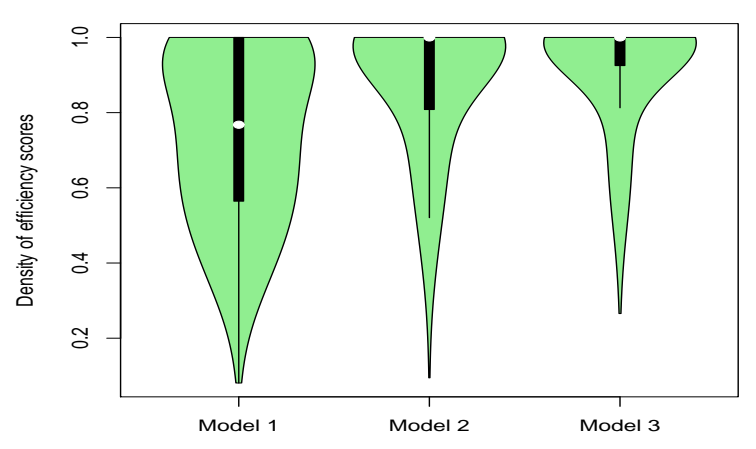

(b) FDH 2008

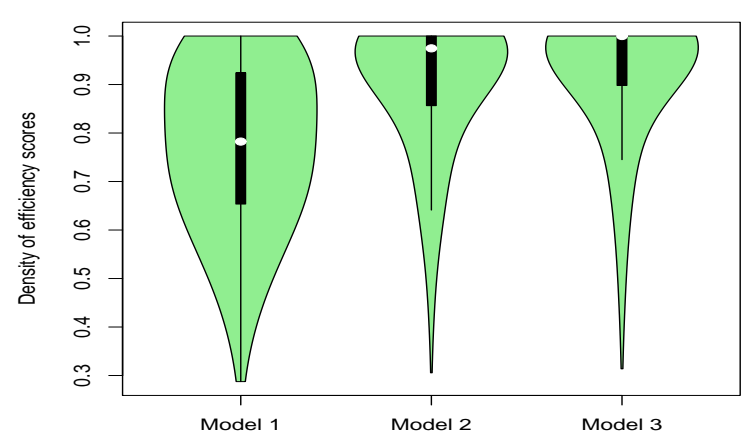

(d) FDH 2009-2012

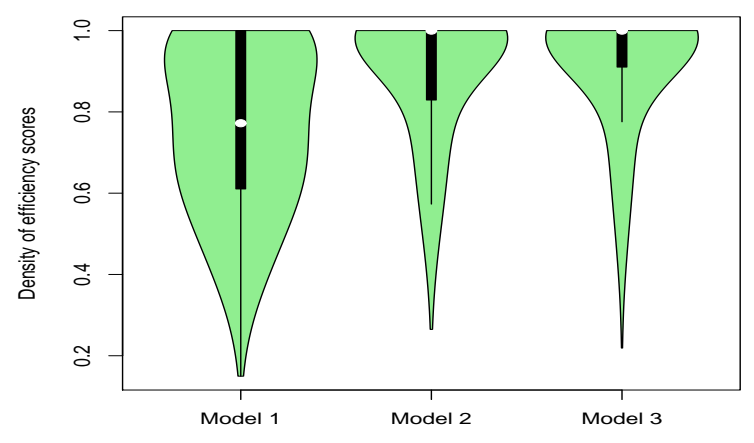

(f) FDH 2013 
Figure 2: Violin plots for order- $m$ and KSW efficiency scores, the three models per year.



(a) Order- $m 2008$

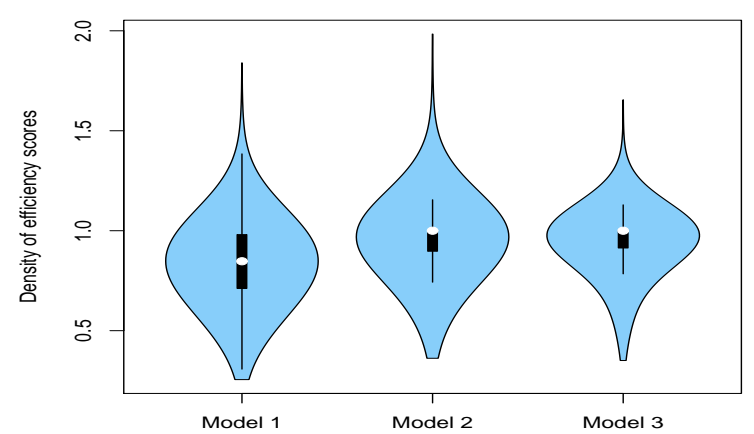

(c) Order-m 2009-2012

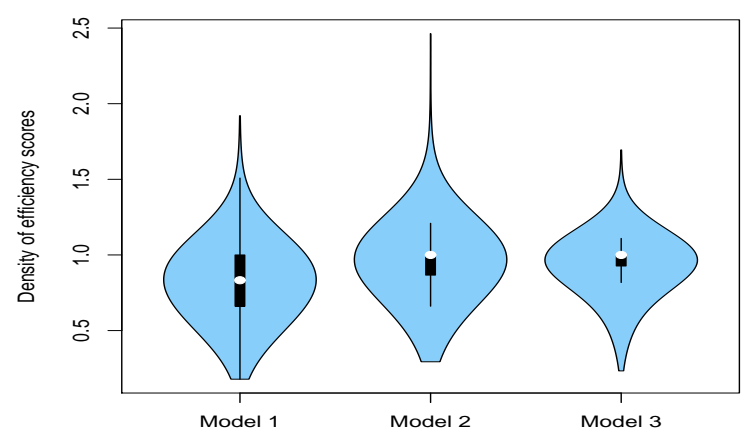

(e) Order- $m 2013$

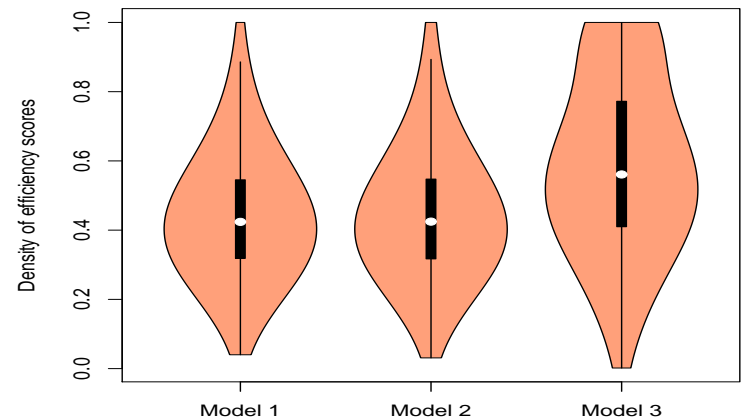

(b) KSW 2008

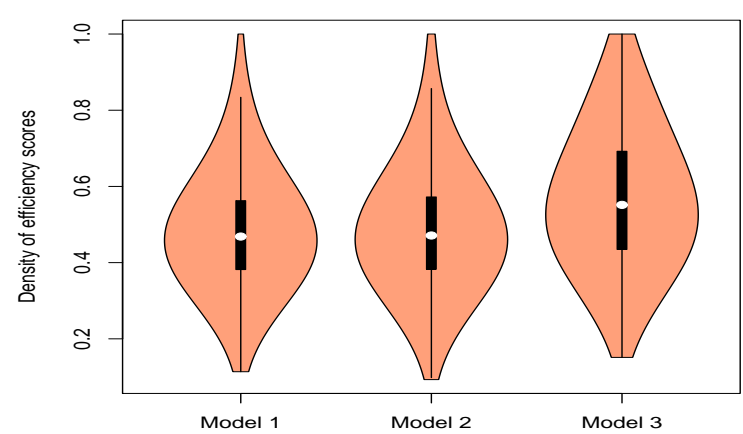

(d) KSW 2009-2012

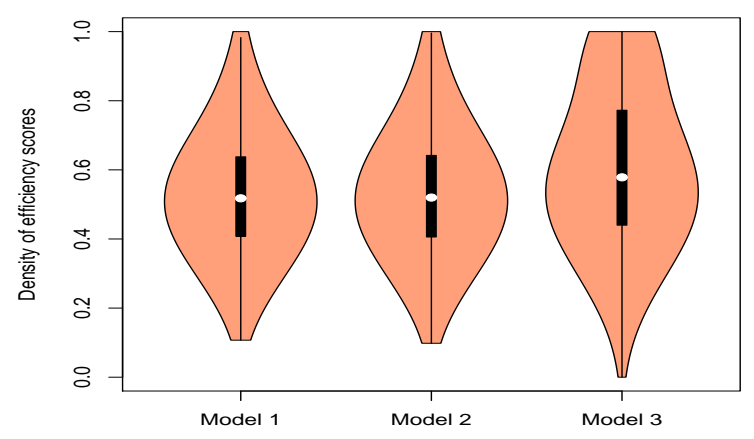

(f) KSW 2013 